\title{
Analysis and Assessment of Behavior of Compacted Soils
}

\author{
D. Venkateswara Rao ${ }^{1}$, Dr. K. Nagendra Prasad ${ }^{2}$, Dr O.Sreedhara ${ }^{3}$, D. \\ Sivaramulu Naidu ${ }^{4}$ \\ ${ }^{1}$ Research Scholar, SVU College of Engineering, Tirupati, India \\ ${ }^{2}$ Registrar, Vikrama Simhapuri, University Nellore, Andhra Pradesh, India \\ ${ }^{3}$ AEE, Irrigation Department, Nellore, Andhra Pradesh, India \\ ${ }^{4}$ Research Scholar, SVU College of Engineering, Tirupati, India
}

\begin{abstract}
Most of the natural soils above ground water table (or above capillary zone) and invariably all the compacted soils in their placement condition are in the state of partial saturation. Unsaturated soils exist all over the world where the weather conditions are such that the annual evaporation potential is in excess of the precipitation. Unsaturated soils in their natural condition are generally found in tropical regions with arid and semi arid conditions. In such regions the soils are formed under peculiar hot and humid climate conditions and the soils so formed are subjected to seasonal moisture deficits. Hence the soils are in the state of partial saturation. All compacted soils in their placement water content are in state of partial saturation. The mechanical behaviour of unsaturated soils is strongly influenced by the presence of both the pore air and the pore water. The mechanisms governing the behaviour of unsaturated soils are quite different and need to be analyzed carefully as these soils are frequently encountered in engineering practice for founding many structures involving infrastructure development. The present investigation considers different soils representing wide spectrum of properties present in this region for probing the compaction and stress-strain characteristics. The soils are tested in quasi saturated state to circumvent the problems associated with the suction measurement and developing a phenomenological model for easy use by practicing engineers.
\end{abstract}

Keywords: natural soils; partial saturation; tropical region; compaction; compressibility; stress-strain.

\section{Introduction}

\subsection{Compressibility}

Volume change and shear strength characteristics of compacted soils have become increasingly important as a consequence of large scale infrastructure projects are being built on such soils. As is widely stated compressibility is one of the most important engineering properties which give an understanding of response of the soil in terms of deformation under a given stress. It is also one of the important constitutive parameters required for constitutive modeling of soils. Compression of soils can be caused either by applying an external stress (stress probe) or by applying a suction (suction probe). Attempts have been made [1], to understand the compressibility response of the saturated soils under both the stress and suction probes. When a stress or suction probe is applied, compression occurs due to expulsion of pore water which is slow and time dependent. Hence, for saturated soils, the compressibility coefficient $\lambda$ or $\mathrm{C}_{\mathrm{c}}$ is uniquely defined independent of the stress probe, being the slope of the virgin compression line. The compression of unsaturated soil under an external, load is essentially due to expulsion of air and internal drainage of pore water, maintaining essentially constant water content conditions. This is because there is no need to for water to flow to a far off boundary when there are air pores close by. With increase in pore water pressure due to increase in total stress, water flows into the adjoining boundary.

Further, it has been brought that the compressibility of air pores is different from that of a water pores for a given stress increment. Consequently the compressibility of the soil mass may not be unique but depends on the initial state of the soil i.e., water content $\mathrm{w}$ and degree of saturation $\mathrm{S}_{\mathrm{r}}$ which reflect the relative amounts of air pores and water pores. And it has been further shown that the response of air pores under an applied suction is different from that under applied stress, although the compressibility of the water pores alone is the same under both types of stress probes. Hence, for a soil, unlike in its saturated state, there is no unique virgin compression path in partly saturated condition by which compressibility coefficient $\lambda$ could be uniquely defined.

Further, it has been shown that the compressibility response of unsaturated soils would be different from that of saturated soils with rate of compression increasing with the stress and tending towards compression path of saturated soils at greater stress levels. The compression paths of different soils compressed from different degrees of saturation would be shown as unique line by using the state parameter $e \sqrt{s_{r}}$ has been 
brought out earlier. The compression index of unsaturated soils therefore can be obtained from the relationship obtained with $e \sqrt{s_{r}}$ and equilibrium pressure for those soils which represent initially loose state.

\subsection{Shear Strength}

The shear strength characteristics of unsaturated soils have become increasingly important in the recent years for solving several geotechnical engineering problems. Also, a clear understanding of mobilization of shearing resistance of compacted soils is required for earth dams, road and railway embankments for their suitability analysis and economic design etc. An understanding of the basic mechanism of shearing resistance is necessary for sorting out certain complex issues like variability of the angle of shearing resistance $\varphi$ or the friction factor $\mathrm{M}$ with suction component and soil state, and hence to finally develop constitutive relations. In saturated soils, the angle of shearing resistance $\varphi$ or the friction factor $M$ is uniquely defined irrespective of the test path and type of testing i.e., drained or undrained. Understanding of the mechanism of mobilization of shearing resistance and defining the angle of shearing resistance $\varphi$ or the friction factor $\mathrm{M}$ uniquely, independent of stress path and type of stress probe has not been satisfactorily done for unsaturated soils. Relatively few experimental data on the behaviour of unsaturated soils are available due to technical difficulties related to both control and measurement of suction. It is essential to properly characterize the stress-strain properties of soil for relevant numerical analyses of geotechnical boundary value problems.

\subsection{Compacted soils}

Unsaturated soils occur widely in the form of compacted fills and natural soils above the water table. A compacted soil is often employed in geotechnical constructions. As a result there are many problems of geotechnical analysis or design where an understanding of mechanical behaviour of unsaturated soils is very important. Despite the fact that different studies exist in literature about compacted soils, the data needed to determine the model parameters required for developing framework for constitutive relationship for these soils are not readily available. The present investigation considers different soils representing wide spectrum of properties present in this region for probing the compaction and stress-strain characteristics. The soils are tested in quasi saturated state to circumvent the problems associated with the suction measurement and developing a phenomenological model for easy use by practicing engineers.

\subsection{Quasi-saturated State}

A detailed study carried out on unsaturated tropical lateritic and saprolitic soils in both compacted and undisturbed states[1], it has been suggested that the value of pore-air pressure would be close to zero for high degrees of saturation (in general above $85 \%$ and in some soils above $90 \%$ ), and under these conditions air voids would be occluded and water voids would be continuous. The state of soil has been termed "quasi-saturated" because it has been observed that the engineering behaviour of the soil in this state is quite similar to its behaviour in a saturated state. Similar findings are also reported in literature $\{[3],[4]\}$.

\subsection{Soils Tested}

Tests were carried out on compacted specimens of tropical soils collected from Rayalaseema region and Nellore of Andhra Pradesh as shown in Fig. 1. The index properties of these soils are presented in Table 1. The disposition of soils on plasticity chart is shown in Figure.2. It may be observed from the Table 1 that the fine fraction is varying from $45 \%$ to $95 \%$ whereas the liquid limit values range from 28.5 to $66 \%$. These index properties indicate that the variability both in terms of fine fraction and liquid limit values encompass wide spectrum of fine grained soils and clayey sand with IS classification ranging from CL to CH and SC.

\section{Compaction Characteristics}

The soil specimens were compacted in three layers using 25 blows per layer of 5.5 pounds rammer. The soil specimens were compacted and tested immediately after ensuring thorough mixing of water with soil. Fig. 3. indicates the water content versus dry density relationship for the soils tested under present investigation. It may be observed that the compaction curves are scattered over a range of maximum dry densities. A closer examination reveals that the scatter is on account of the grain size distribution and plasticity characteristics. It may be observed that the compaction characteristics for soils obtained from Nellore and Manubolu are closely spaced in comparison with the other three soils. It may be further noticed that these two soils have the plastic limit values of nearly same and also the modified liquid limit values. The compaction curves for the other soils also are placed according as their respective plastic limit and modified plastic limit values. These experimental findings indicate that the compaction characteristics relate to plastic limit and modified plastic limit. 


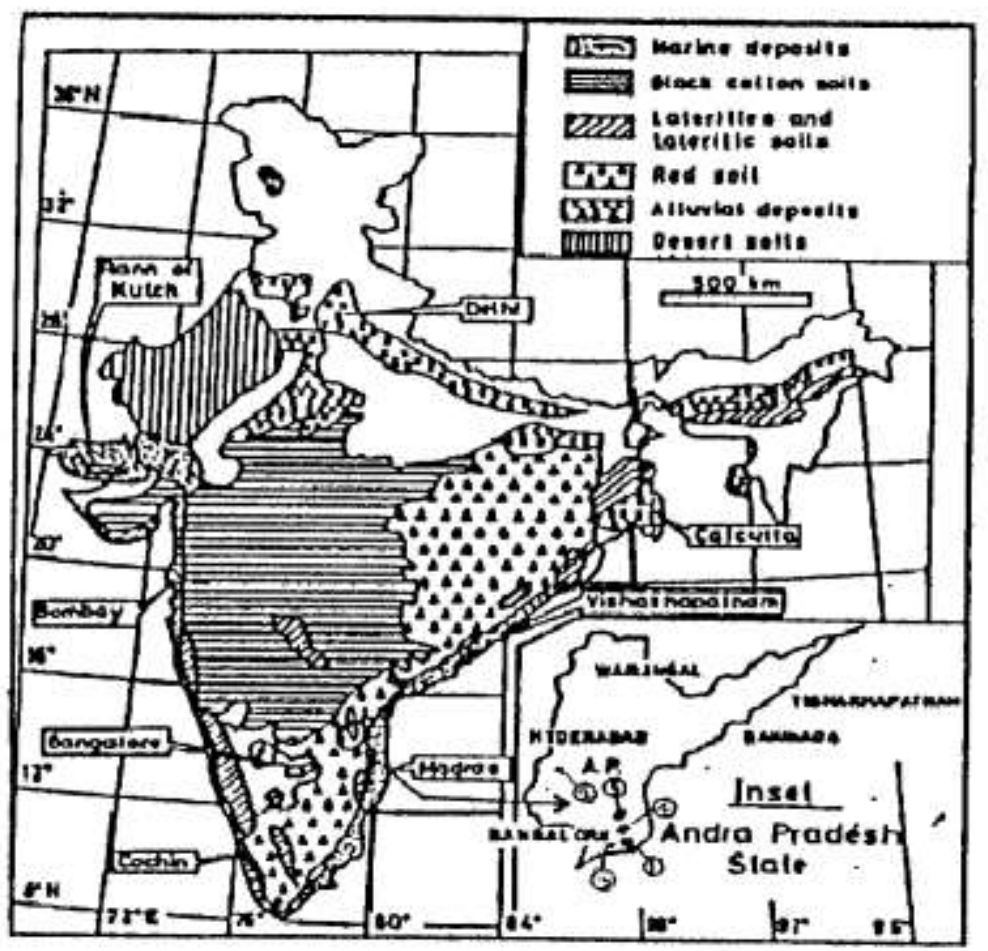

Fig. 1.Soil map with details of locations of sampling shown in the inset figure

Table 1 Index properties of soils applied in the study

\begin{tabular}{|c|c|c|c|c|c|}
\hline \multirow[b]{2}{*}{ Property } & \multicolumn{5}{|c|}{ Location } \\
\hline & $\begin{array}{c}\text { Perumalla } \\
\text { Palli }\end{array}$ & Kurnool & $\begin{array}{c}\text { Byragipatted } \\
a \\
\end{array}$ & Manubolu & Nellore \\
\hline \% Gravel & 1.6 & 0.52 & 0.4 & 0 & 1.6 \\
\hline$\%$ Sand & 24.0 & 13.88 & 4.2 & 45.6 & 54.0 \\
\hline$\%$ Silt + Clay & 74.4 & 85.6 & 95.4 & 54.4 & 44.4 \\
\hline$\%$ passing $425 \mu(F)$ & 85.0 & 93.8 & 95.8 & 94.6 & 71.8 \\
\hline Liquid limit (\%) & 45 & 66 & 55 & 29 & 41 \\
\hline Plastic Limit (\%) & 20 & 28 & 28 & 18 & 17 \\
\hline Plasticity Index (\%) & 25 & 38 & 27 & 11 & 24 \\
\hline IS Classification & $C I$ & $\mathrm{CH}$ & $\mathrm{CH}$ & $C L$ & $S C$ \\
\hline $\begin{array}{c}\text { Modified liquid limit, } \\
W_{L M}(\%)\end{array}$ & 41.6 & 61.9 & 52.7 & 26.7 & 29.4 \\
\hline
\end{tabular}

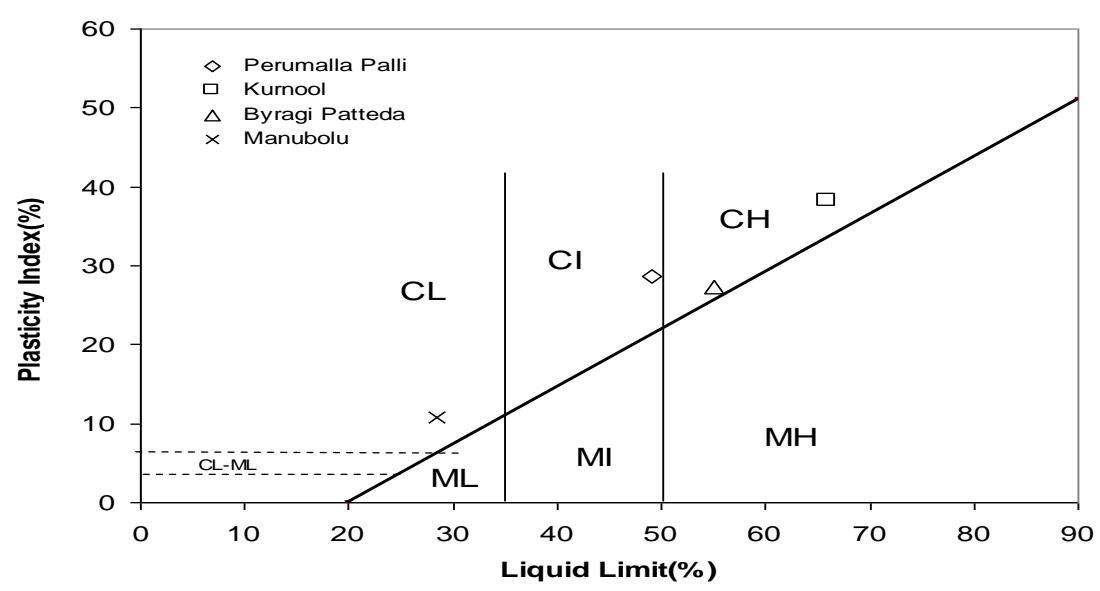

Fig. 2. Location of soil samples tested on plasticity chart 


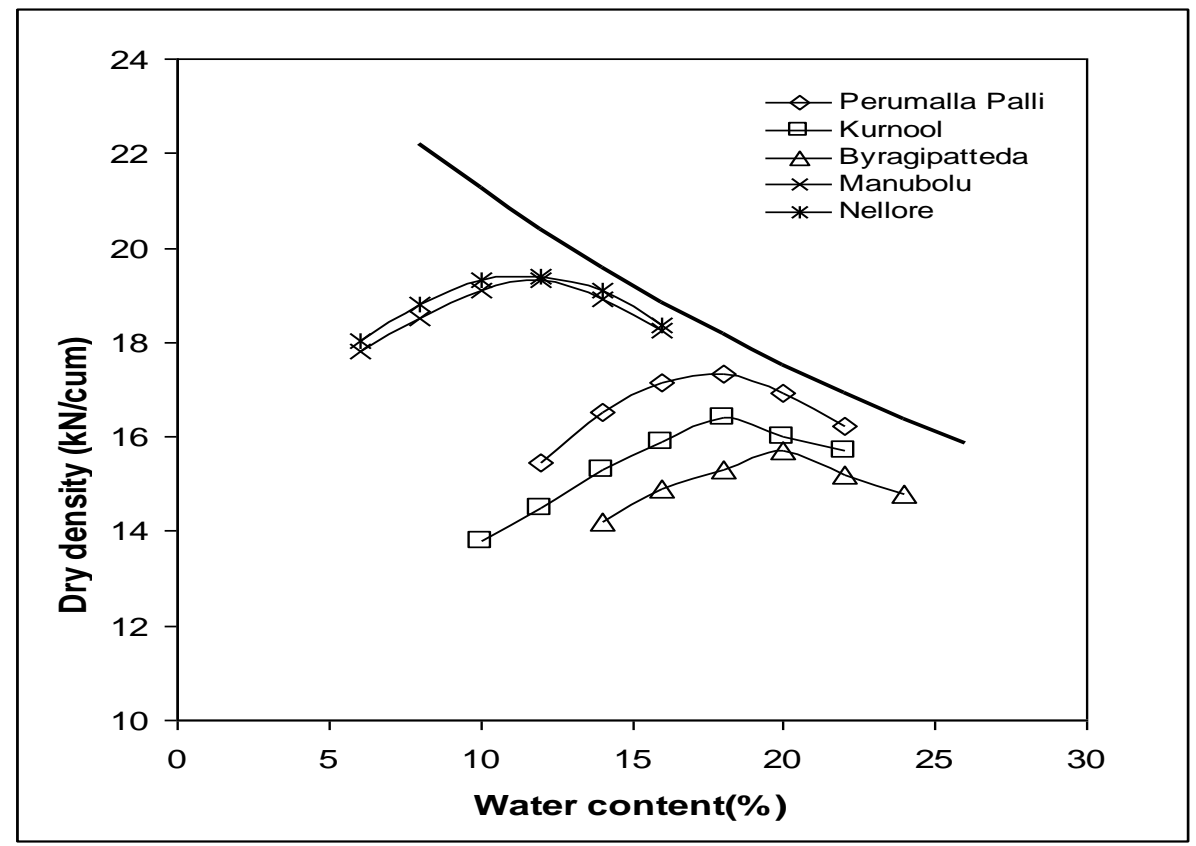

Fig. 3. Water content versus Dry density

\subsection{Introduction}

\section{Behaviour Under Compression}

When a stress or suction probe is applied for saturated soils, compression occurs due to expulsion of pore water which is slow and time dependent. The compression path is unique under both stress probe and suction probe Fig. 4. Hence, for saturated soils, the compressibility coefficient $\lambda$ or $\mathrm{C}_{\mathrm{c}}$ is uniquely defined independent of the stress probe, being the slope of the virgin compression line. However the case of unsaturated soils is quite different as there would be component of resistance to compression from occluded air and surface tension considerations. Therefore, it is important to study the compression paths of unsaturated soils both at compacted state and loose state in relation to the compression path of saturated soil for developing the framework

\subsection{Compression Path from Partly Saturated State}

The soils are mixed with water content of $10 \%$ of respective liquid limit values. The soil samples are wrapped in plastic cover and are kept in desiccator for about 8 hours for uniform absorption of moisture. The samples are transferred to consolidation ring taking care to see that the soil particles are kept at possible loose state representing dumped condition of the soil. The specimens thus placed are monotonically compressed with each increment of pressure being placed until the equilibrium state is reached. After compressing the specimens up to $80 \mathrm{kPa}$ the samples are subjected to inundation by providing access to the water potential. Typical compression data of soils are shown in Fig. 4 to 5 , in the form of soil state versus externally applied pressure relationships for both constant water content and inundated conditions. During the progress of compression with increase in stress the void ratio gradually diminishes at constant water content leading to increase in saturation. The compression paths for unsaturated soils at initially loose state are likely to converge with the normal compression line for saturated soils as a consequence of increase in saturation observed with stress. This is due to the fact that volume of water remains the same with decrease in volume of voids and hence increases in degree of saturation. The new lower equilibrium state is obtained as a consequence of reduction in surface tension due increased degree of saturation. It may be seen from these figures that the soils tend to collapse under inundation as the resistance to compression reduces with increase of pore water and hence increase in effective stress . The collapse is observed for all soils under constant loading under inundation. 


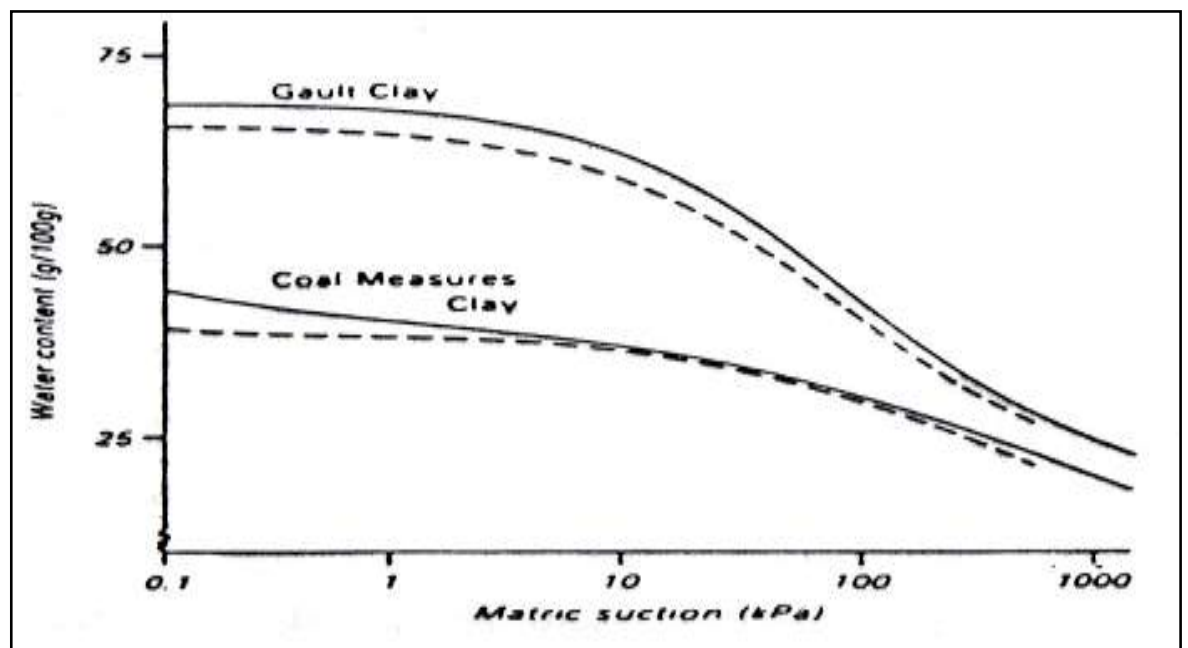

Fig. 4. Comparison of water release characteristics obtained by consolidation (dotted lines) and by sand suction table-pressure membrane apparatus (thick lines) for two sieved and rewetted sub soil clays (Reeve and Carter, 1991).

\subsection{Compression Path from Compacted State}

Predetermined quantity of oven dried soil, cooled to room temperature in an air tight desiccator, mixed with optimum moisture content compacted statically in the oedometer rings $(6 \mathrm{~cm}$ diameter and $2 \mathrm{~cm}$ height). The compacted sample was submerged in water at a seating pressure of $5 \mathrm{kPa}$. Loads were placed on oedometer to obtain vertical pressure of 10, 20, 40, 80, 160, 320 and $640 \mathrm{kPa}$. Each pressure was applied for a period of 24 hours. The compression paths of five soils compacted at its optimum moisture content shown in Figs. 5 to 9. It may be observed that the compression paths show rigid response until the pressure corresponding to intrinsic compression line is reached. There upon the compression paths for soil samples obtained show good agreement with compression path of intrinsic compression line at greater pressures. This behavior is quite similar to that of over-consolidated soils. The pre-consolidation pressure characterized by meeting of the compression path of the compacted soil with the intrinsic compression line is found to be different for different soils. The variation is due to the basic differences in moulding water content and consequent fabric and structure of the soils. It may also be observed that the pre-consolidation pressure is nearly same for the soils having same initial moisture content.

In retrospect, the experimental investigation reveals that the soils compressed from initially loose and unsaturated state lie on the right hand side of the normal compression line of same soil compressed under saturation. The soil samples compressed from compacted state corresponding to optimum moisture content lie on left hand side of the normal compression line. The compression paths of the compacted specimens are akin to that of over consolidated state. These compression paths yield at very high stress levels.

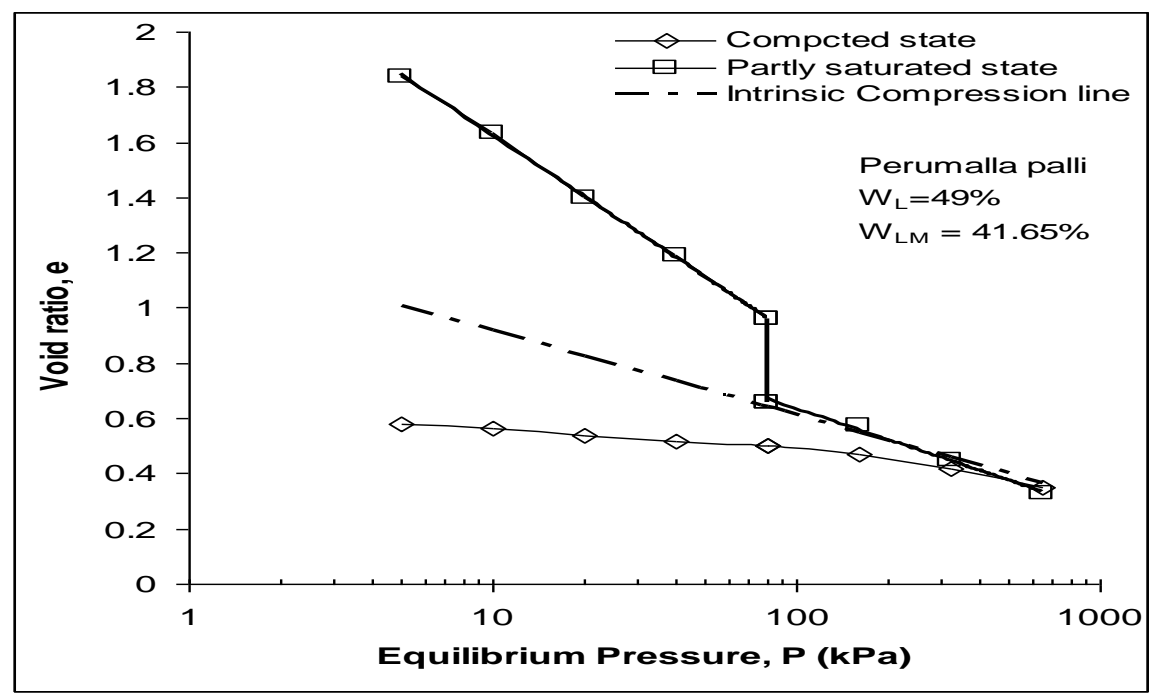

Fig. 5. Soil state vs. externally applied pressure - For Perumalla palli soil 


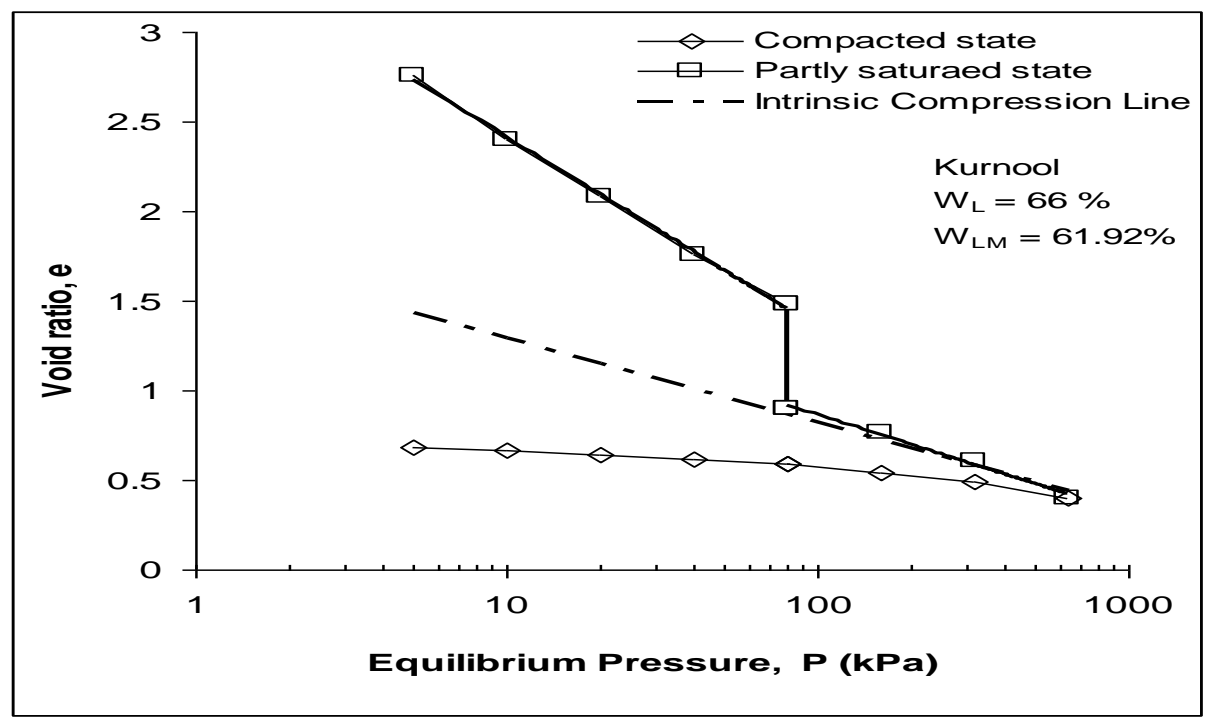

Fig. 6.Soil state vs. externally applied pressure- For Kurnool soil

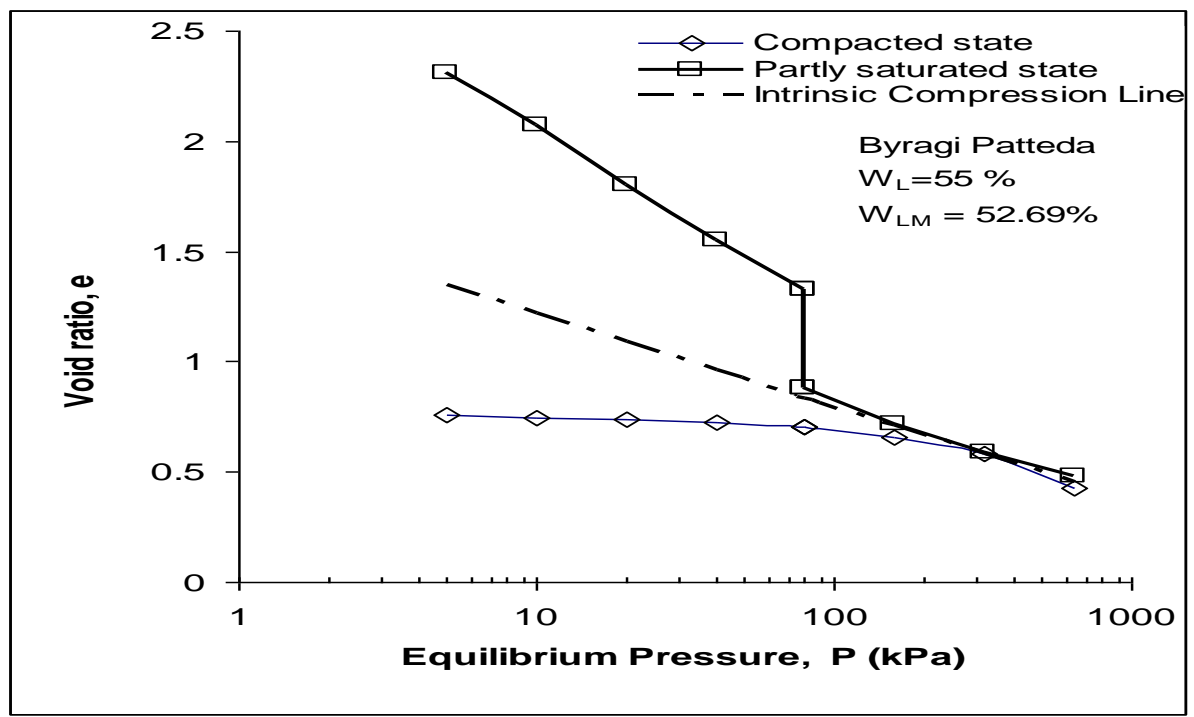

Fig. 7.Soil state vs. externally applied pressure- For Byragipatteda soil

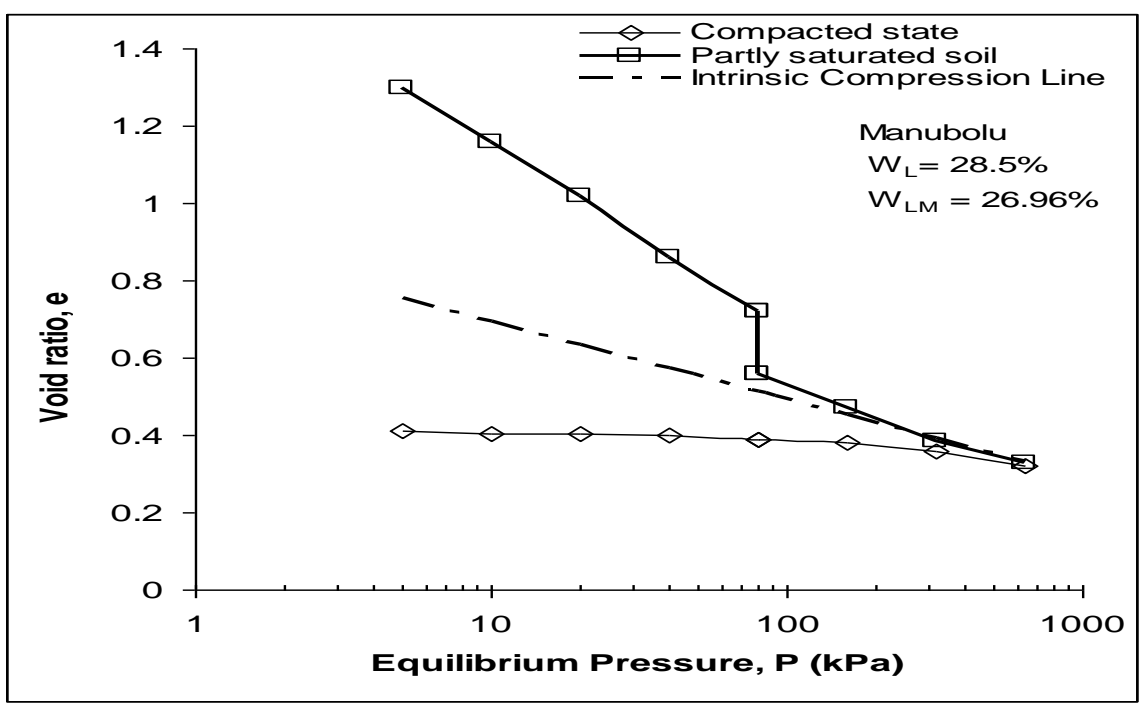

Fig. 8. Soil state vs. externally applied pressure- For Manubolu soil 


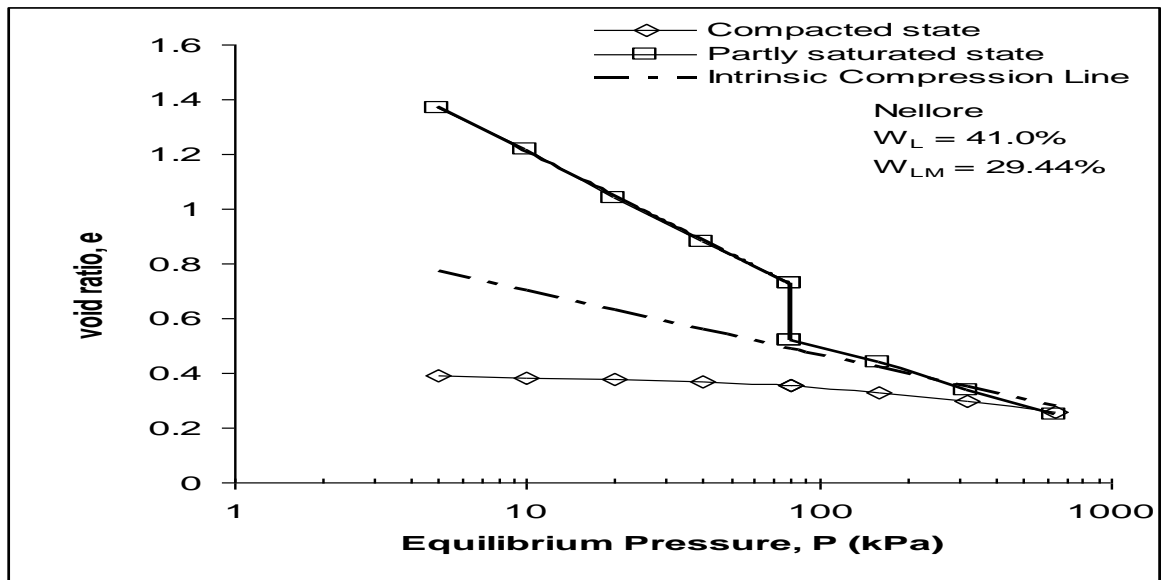

Fig .9. Soil state vs. externally applied pressure - For Nellore soil

\subsection{Introduction}

\section{Behaviour Under Shear}

The design of embankments, earthen dams, fills, and land reclamation works deals with slope stability analysis. For carrying out systematic stability analysis the shear strength characteristics forms the essential basis. Also, while trying to understand the behavior of boundary value problem under drained and undrained situations a thorough knowledge of shear strength parameters is a pre-requisite. Accordingly, a series of experiments are conducted under triaxial testing apparatus using under different confining pressures to study the stress-strain response.

\subsection{Sample Preparation}

The soil samples are mixed with moisture content corresponding to their respective optimum moisture contents and are wrapped in plastic covers and kept in desiccators for about 6-8 hours for allowing equitable distribution of moisture in the soil specimen. These soil samples are then subjected to light compaction according to the specifications stipulated in Bureau of Indian Standard Procedures. A table extractor has been used to obtain the samples from the compaction mould so through split mould to obtain samples of uniform dimensions each time. For each sample three consolidated undrained tests were performed at different cell pressures. The three cell pressures are so chosen to understand the stress-strain response before the yield stress and after the yield stress.

\subsection{Geotechnical Digital System (GDS)}

Tests were conducted in a Geotechnical Digital System (GDS) using computer controlled triaxial cell. The soil specimens were placed in a triaxial cell and were back saturated before consolidation stage. The cell pressure was raised gradually using saturation ramp to 500 to $700 \mathrm{kPa}$ depending on the degree of saturation of soil and back pressure was also raised simultaneously such that the net effective pressure is of the order of about $20 \mathrm{kPa}$. The B-parameter at initial stage of testing was noticed to be of the order of $0.3-0.45$ for all the soils, when these specimens were prepared at their respective optimum moisture contents, and it has gone up to 0.85 to 0.90 just before the commencement of consolidation stage. To obtain this state of quasisaturation the specimens have taken a time of about 14 to 20 hours using the saturation ramp. The characteristics of samples before and after testing together with conditions of testing are presented in Table 2 and 3. It may be seen from the table that the measured values of degree of saturation vary from 74 to $85 \%$.

\subsubsection{Test results}

The experimental results are presented in Figs. 10 to 25. It may be seen that the stress strain response for the compacted soils is dependent on confining pressure though the initial void ratios are nearly same. Greater the confining pressure greater is the peak stress. The pore pressures are noticed to be positive owing to quasi saturated states obtained by back saturation.

The values of mean principal stress and deviator stress are evaluated at critical state for each sample based on the test results shown in Figs. 10 to 25. These values are represented in Figs. 26 to 30. It may be seen that an intercept is obtained on deviatoric stress axis which is not noticed for normally consolidated soils. This intercept is denoted by ' $c$ ' which is a characteristic feature of compacted soils. This value seems to be proportional to initial degree of saturation for the soils tested. This value of $\mathrm{c}$ appears to be bearing a direct relationship with measured suction as may be seen from the figs. 31 and 32 with a relationship of $c=0.42 S$ 
with a correlation coefficient of 0.989 [5]. This observation forms the basis for appropriately modifying wheeler's model.

Table 2 Observations of samples for consolidated un-drained triaxial test

\begin{tabular}{|c|c|c|c|c|c|c|c|c|c|c|c|c|}
\hline & \multirow{2}{*}{\multicolumn{3}{|c|}{$\begin{array}{c}\text { Perumalla palli } \\
\text { Cell Pressure } \\
(k P a)\end{array}$}} & \multirow{2}{*}{\multicolumn{3}{|c|}{$\begin{array}{c}\text { Kurnool } \\
\text { Cell Pressure } \\
(\mathrm{kPa})\end{array}$}} & \multirow{2}{*}{\multicolumn{3}{|c|}{$\begin{array}{c}\text { Byragipatteda } \\
\text { Cell Pressure } \\
(\mathrm{kPa})\end{array}$}} & \multirow{2}{*}{\multicolumn{3}{|c|}{$\begin{array}{c}\text { Manubolu } \\
\text { Cell pressure } \\
(\mathrm{kPa})\end{array}$}} \\
\hline & & & & & & & & & & & & \\
\hline & 50 & 200 & 300 & 50 & 300 & 400 & 25 & 300 & 400 & 25 & 300 & 400 \\
\hline Do (mm) & 37.5 & 37 & 37 & 37.5 & 37.5 & 38 & 38 & 37.5 & 38 & 38 & 38 & 38 \\
\hline Lo (mm) & 75 & 76 & 75 & 75 & 75 & 74 & 76 & 75 & 76 & 76 & 76 & 76 \\
\hline Wo $(g)$ & 168 & 166 & 165 & 159 & 166 & 168 & 167 & 162 & 167 & 183 & 185 & 184 \\
\hline $\mathrm{W}_{\mathrm{i}(\%)}$ & 17.8 & 17.8 & 17.8 & 19.4 & 19.4 & 19.4 & 18.1 & 18.1 & 18.1 & 11.5 & 11.5 & 11.5 \\
\hline$\gamma_{\mathrm{d}(\mathrm{g} / \mathrm{cc})}$ & 1.72 & 1.73 & 1.74 & 1.61 & 1.68 & 1.68 & 1.64 & 1.63 & 1.64 & 1.90 & 1.93 & 1.91 \\
\hline $\mathrm{e}_{\mathrm{o}}$ & 0.57 & 0.56 & 0.55 & 0.64 & 0.62 & 0.61 & 0.65 & 0.66 & 0.65 & 0.42 & 0.40 & 0.41 \\
\hline$S_{\mathrm{r}}(\%)$ & 84.3 & 85.8 & 87.2 & 81.8 & 84.5 & 85.8 & 75.2 & 74.0 & 75.2 & 74.0 & 78.0 & 75.7 \\
\hline $\mathbf{L}_{\mathrm{f}}(\mathbf{m m})$ & 64 & 62 & 62 & 61 & 61 & 68 & 68 & 74.1 & 72.0 & 61 & 63 & 67.2 \\
\hline $\mathbf{W}_{\mathbf{f}(\%)}$ & 21.4 & 21.0 & 21.7 & 27.5 & 24.3 & 19.7 & 25.9 & 23.7 & 24.8 & 16.7 & 15.5 & 14.2 \\
\hline
\end{tabular}

Table: 3 Details of $\mathrm{CU}$ Triaxial shear tests on different soils

\begin{tabular}{|c|c|c|c|c|c|c|}
\hline Test & $w_{f}(\%)$ & $Y_{d}\left(k N / m^{3}\right)$ & $S_{\text {i }}(\%)$ & $\begin{array}{c}\sigma_{3} \\
(\mathbf{k P a})\end{array}$ & $\frac{\left(\sigma_{1},-\sigma_{3}\right)_{\max }}{2}$ & $\frac{\left(\sigma_{1}{ }^{\prime}+\sigma_{3}{ }^{\prime}\right)_{\max }}{(\mathbf{2}}$ \\
\hline A-1 & 21.4 & 17.2 & 84.5 & 50 & 54.3 & 76.8 \\
\hline A-2 & 21.0 & 17.3 & 85.8 & 200 & 59.85 & 215 \\
\hline A-3 & 21.7 & 17.4 & 87.4 & 300 & 90.2 & 337.8 \\
\hline B-1 & 27.5 & 16.5 & 82.3 & 50 & 44.7 & 81.4 \\
\hline B-2 & 24.3 & 16.7 & 85.9 & 300 & 122.0 & 404 \\
\hline B-3 & 19.7 & 16.8 & 85.8 & 400 & 157 & 538 \\
\hline $\mathrm{C}-1$ & 25.9 & 16.3 & 80 & 25 & 31.98 & 49.2 \\
\hline C-2 & 23.7 & 16.4 & 80.7 & 300 & 79.85 & 345 \\
\hline $\mathrm{C}-3$ & 24.8 & 16.3 & 80 & 400 & 94.95 & 449.4 \\
\hline D-1 & 16.7 & 18.2 & 78.8 & 25 & 46.45 & 104 \\
\hline D-2 & 15.5 & 18.3 & 79.6 & 300 & 163.8 & 347 \\
\hline D-3 & 14.2 & 18.7 & 85.9 & 400 & 217.5 & 472 \\
\hline
\end{tabular}

A-Perumalla palli

B-Kurnool

C-Byragipatteda

D-Manubolu

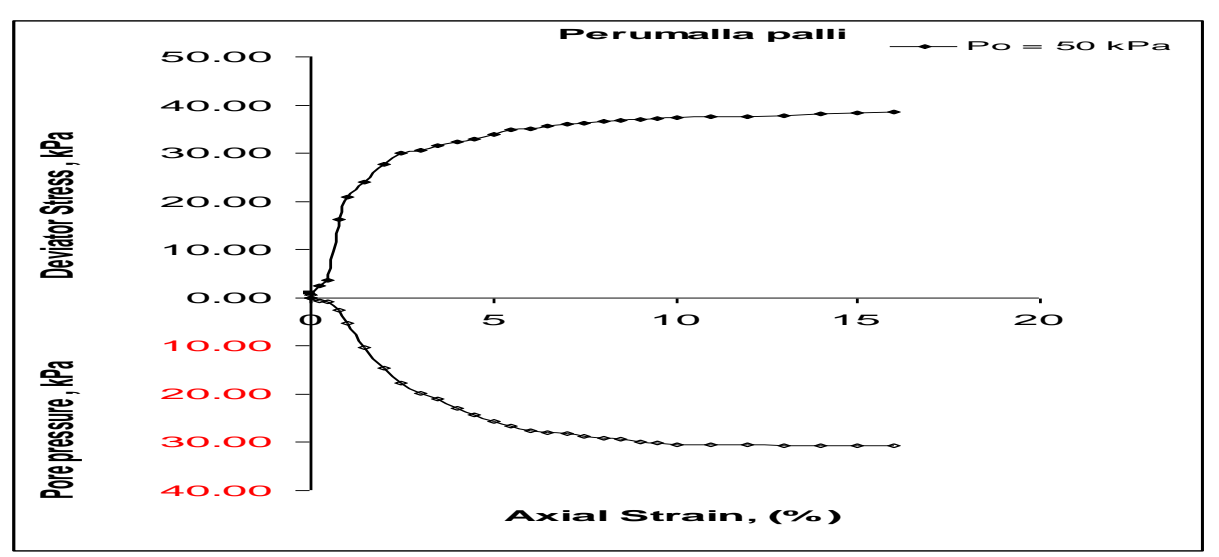

Fig. 10.Stress-Strain-Pore water pressure response of compacted soil under confining pressure $50 \mathrm{kPa}-$ For Perumalla palli soil 


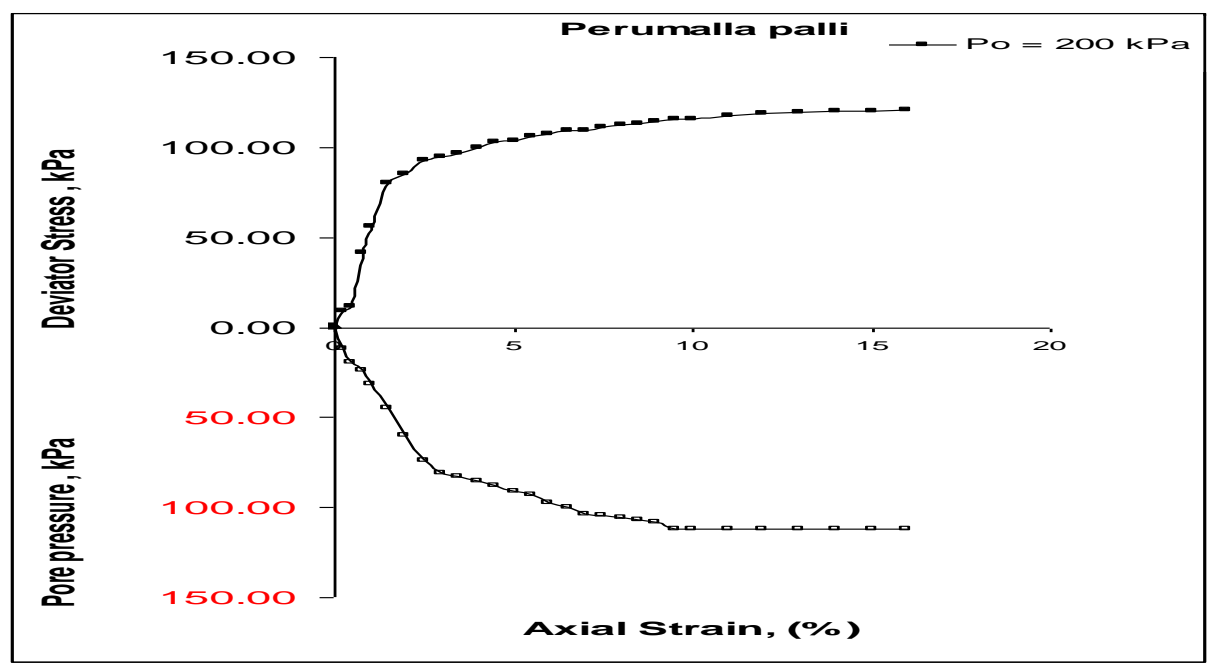

Fig. 11. Stress-Strain-Pore water pressure response of compacted soil under confining pressure $200 \mathrm{kPa}-$ For Perumalla palli soil

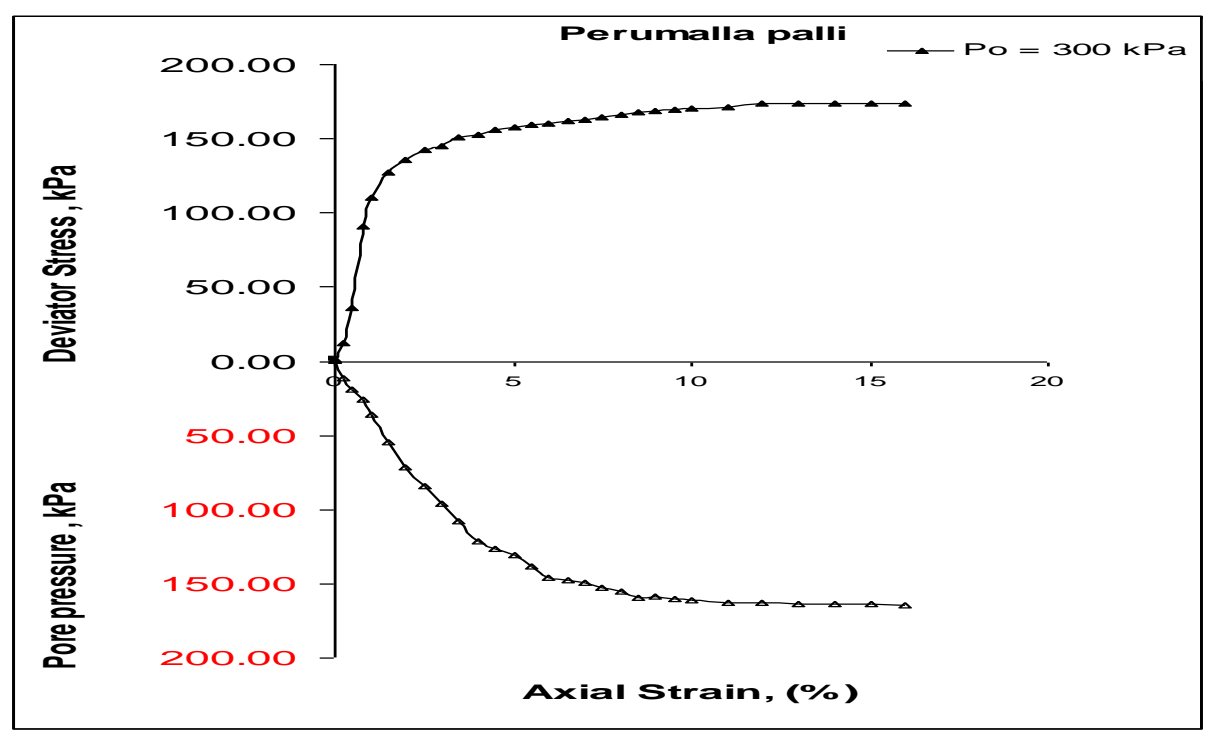

Fig. 12.Stress-Strain-Pore water pressure response of compacted soil under confining pressure $300 \mathrm{kPa}$ - For Perumalla palli soil

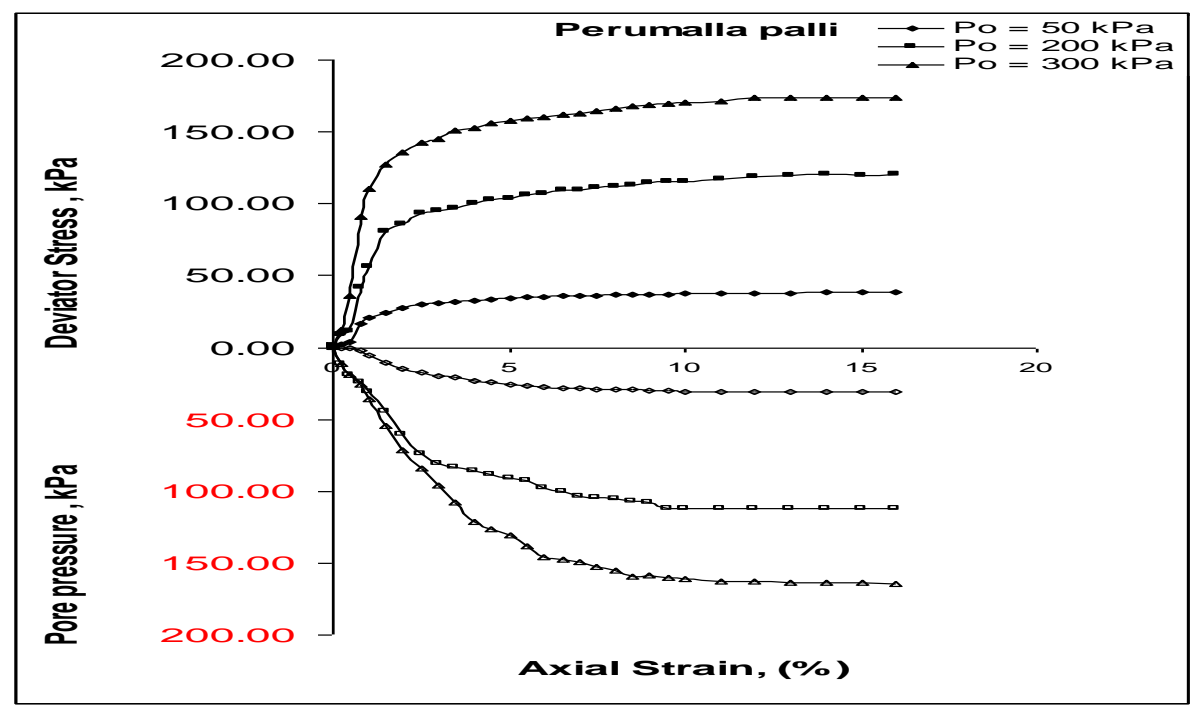

Fig. 13.Stress-Strain-Pore water pressure response of compacted soil - For Perumalla palli soil 


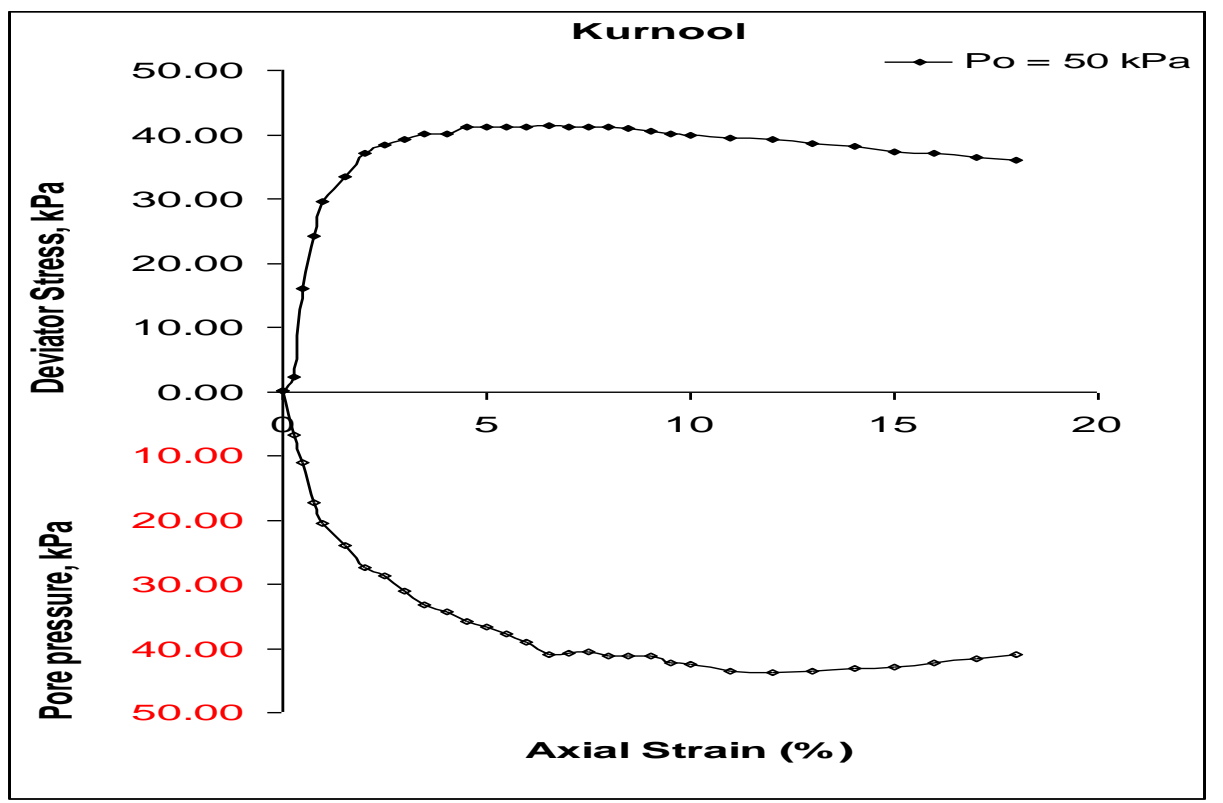

Fig. 14.Stress-Strain-Pore water pressure response of compacted soil under confining pressure $50 \mathrm{kPa}-$ For Kurnool soil

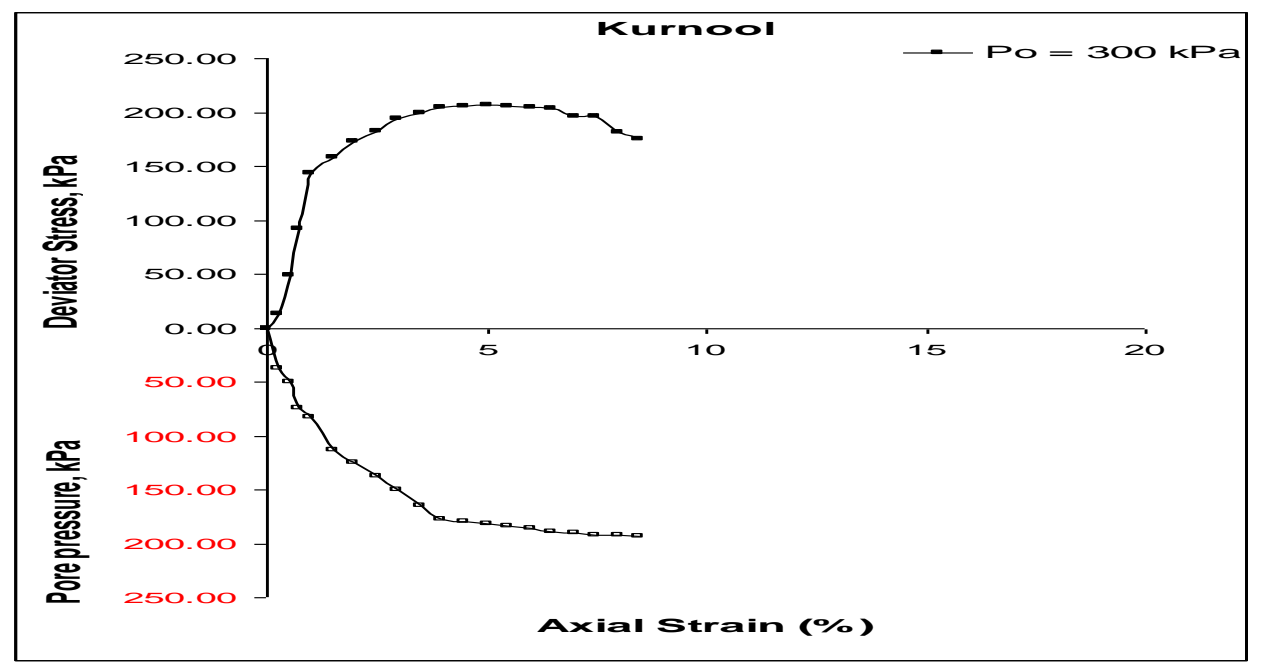

Fig. 15.Stress-Strain-Pore water pressure response of compacted soil under confining pressure $300 \mathrm{kPa}$ - For

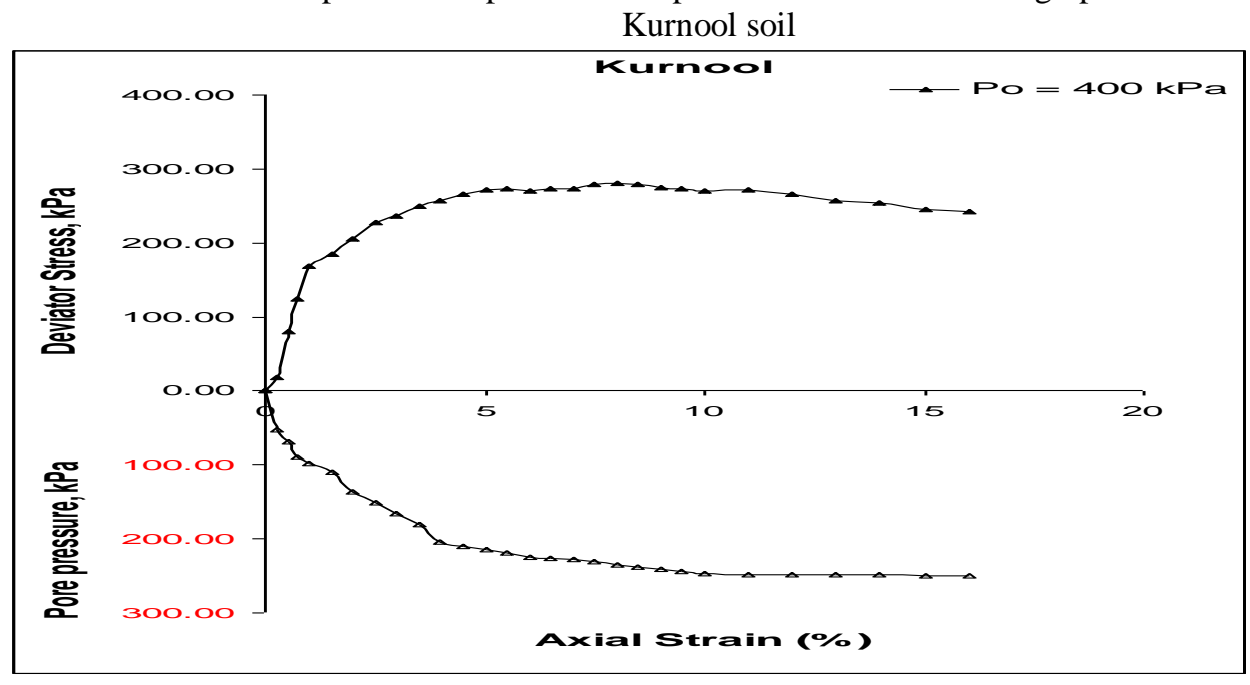

Fig. 16.Stress-Strain-Pore water pressure response of compacted soil under confining pressure $400 \mathrm{kPa}$ - For Kurnool soil 


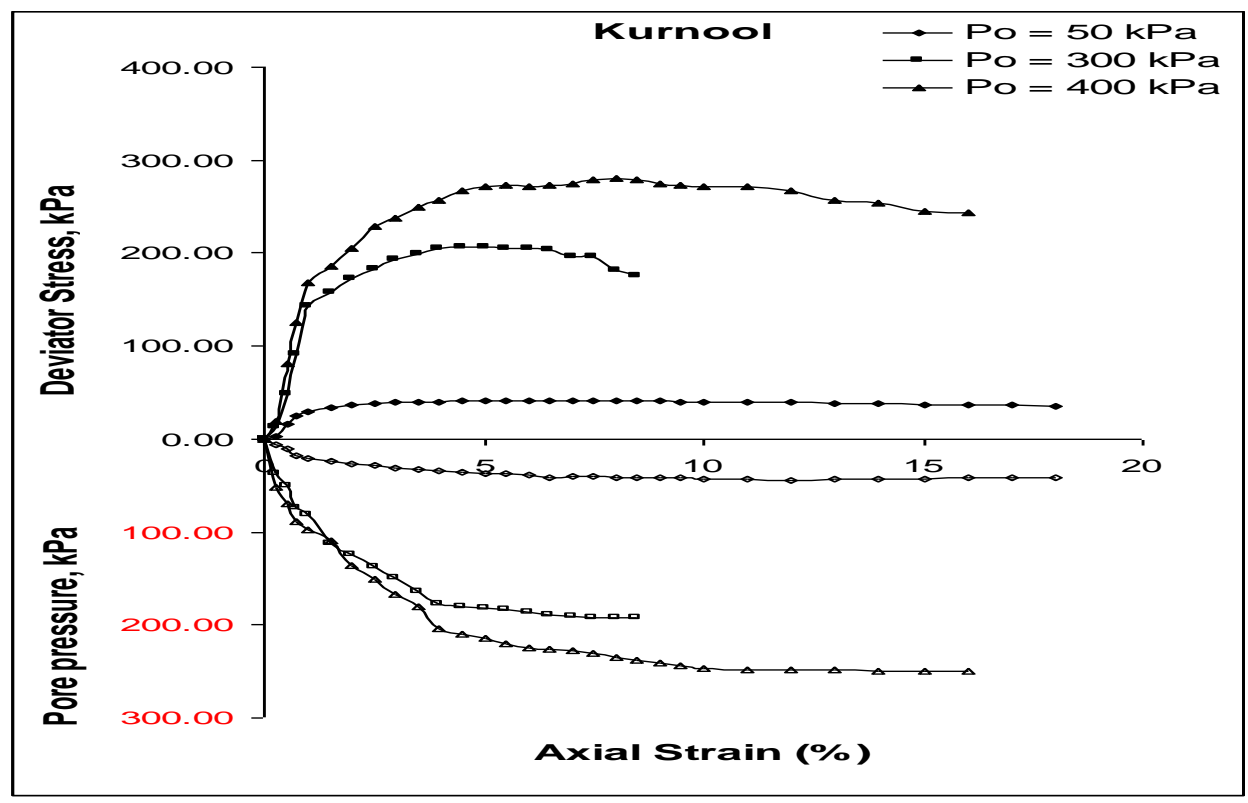

Fig. 17.Stress-Strain-Pore water pressure response of compacted soil - For Kurnool soil

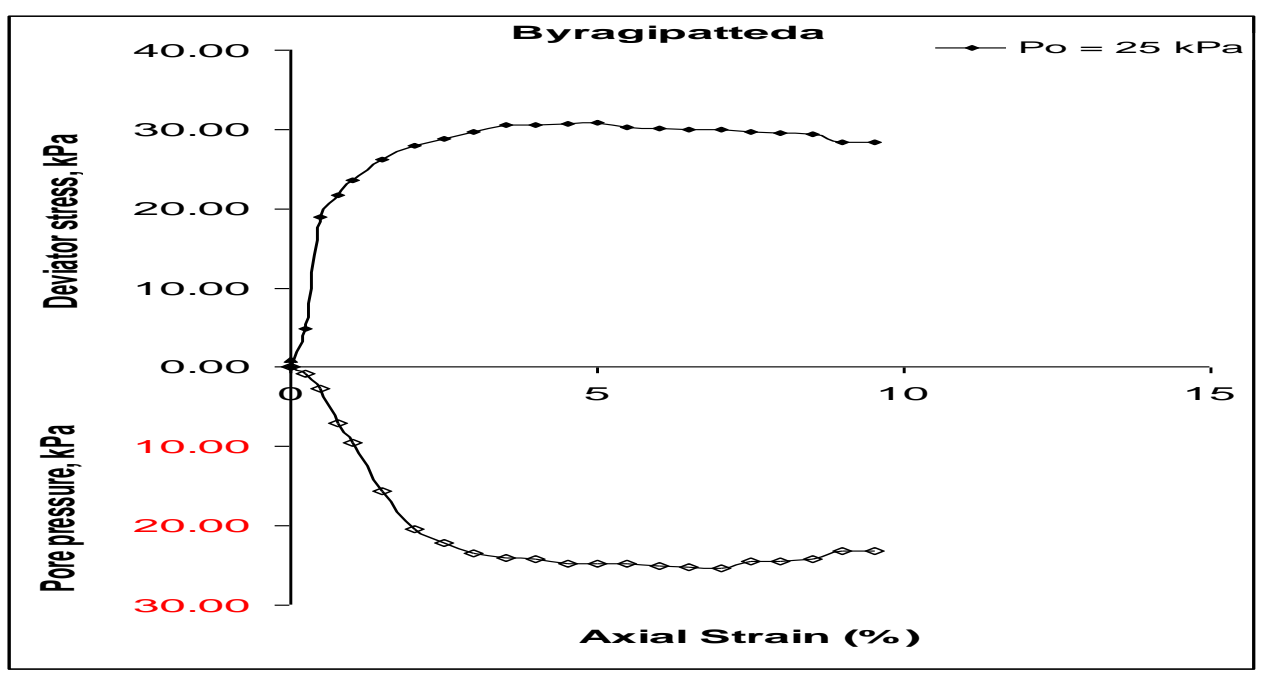

Fig. 18.Stress-Strain-Pore water pressure response of compacted soil under confining pressure $25 \mathrm{kPa}$ - For Byragipatteda soil

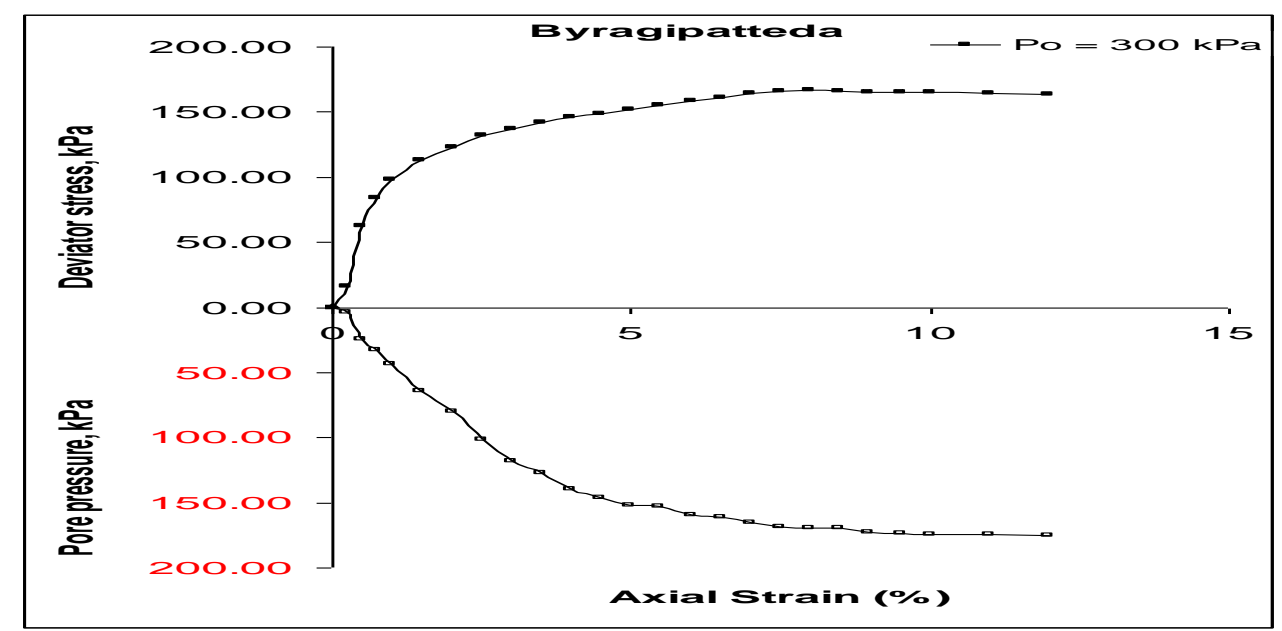

Fig. 19.Stress-Strain-Pore water pressure response of compacted soil under confining pressure $300 \mathrm{kPa}-$ For Byragipatteda soil 


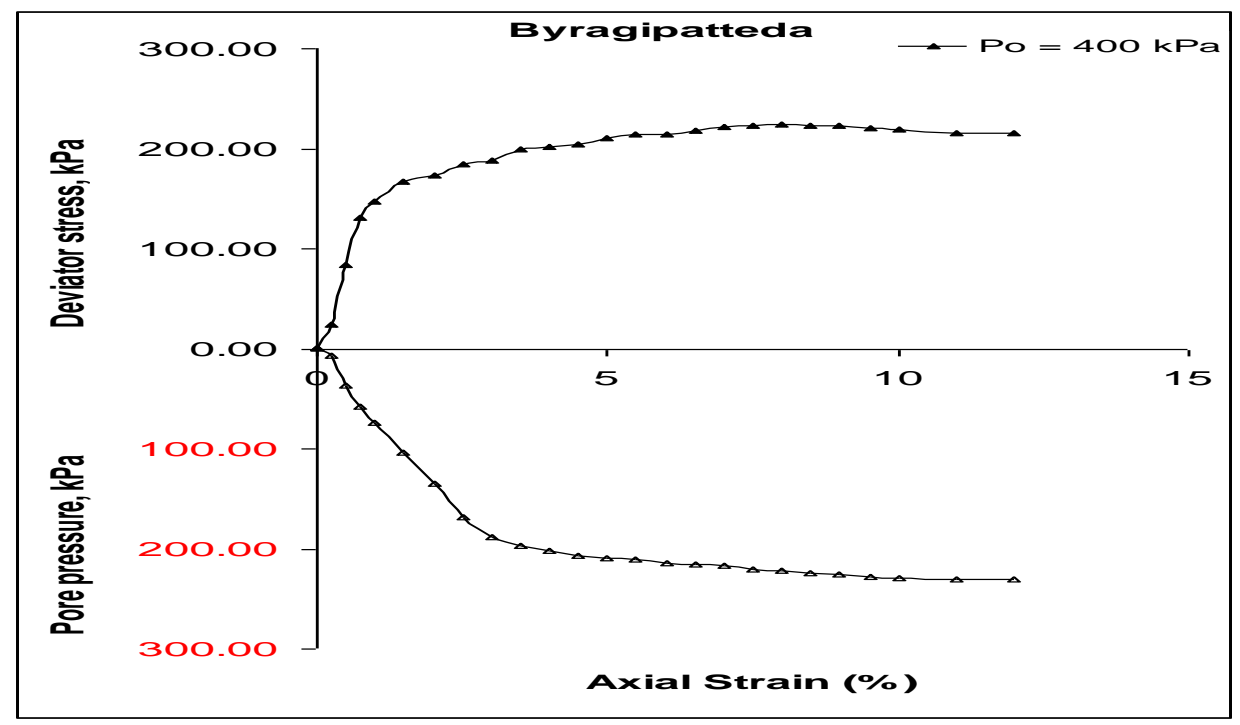

Fig. 20.Stress-Strain-Pore water pressure response of compacted soil under confining pressure $400 \mathrm{kPa}$ - For Byragipatteda soil

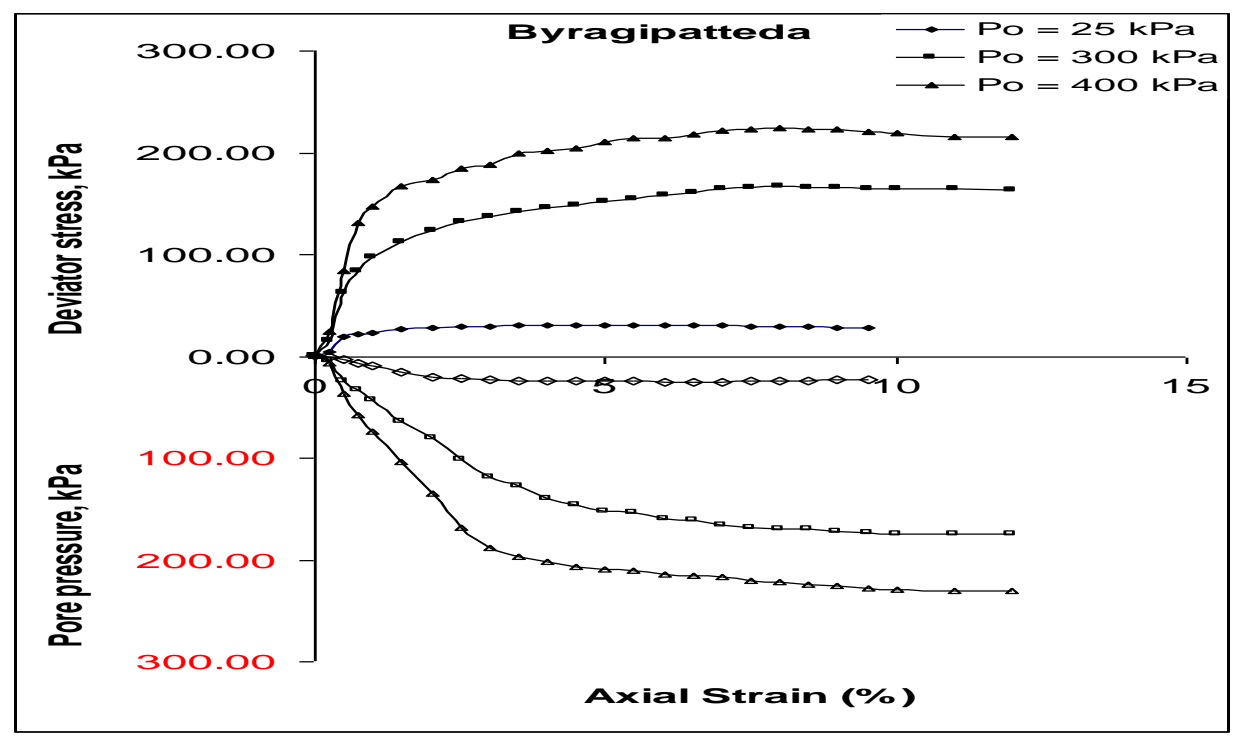

Fig. 21.Stress-Strain-Pore water pressure response of compacted soil - For Byragipatteda soil

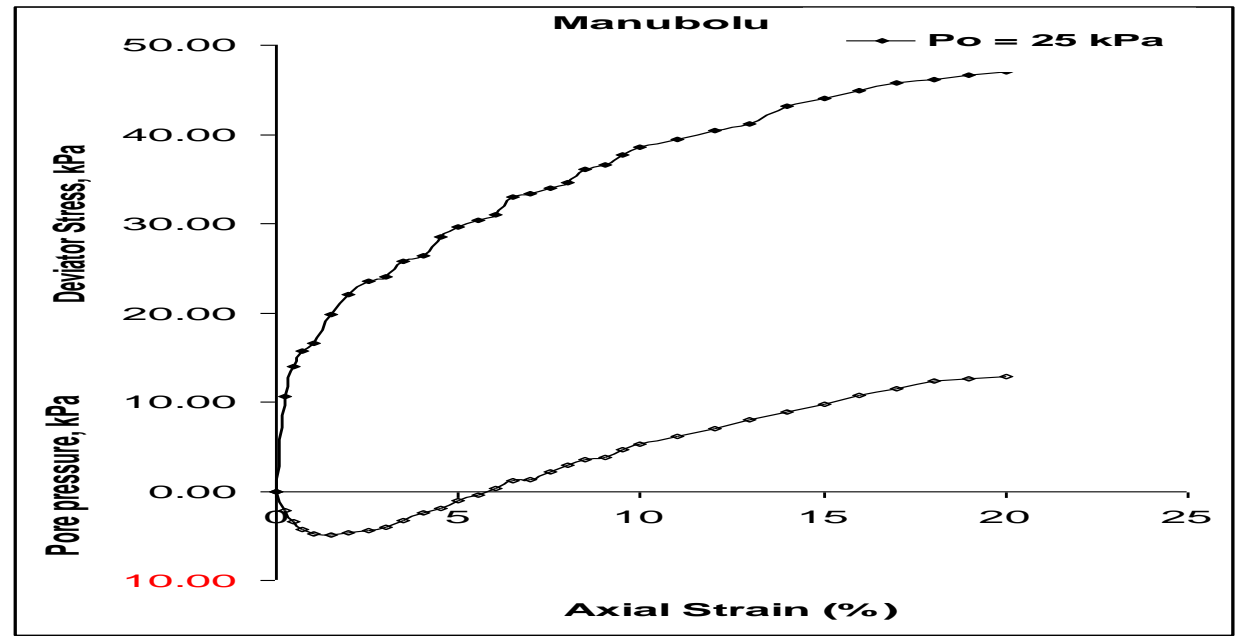

Fig. 22.Stress-Strain-Pore water pressure response of compacted soil under confining pressure $25 \mathrm{kPa}$ - For Manubolu soil 


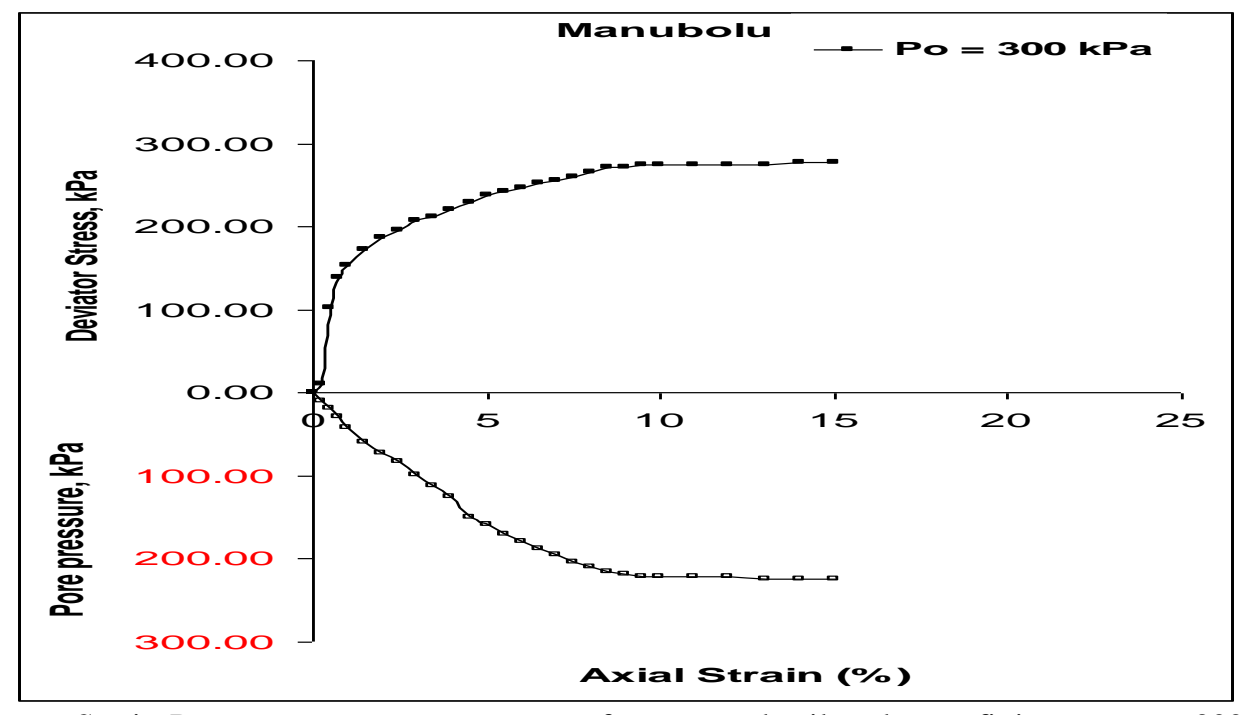

Fig. 23.Stress-Strain-Pore water pressure response of compacted soil under confining pressure $300 \mathrm{kPa}$ - For Manubolu soil

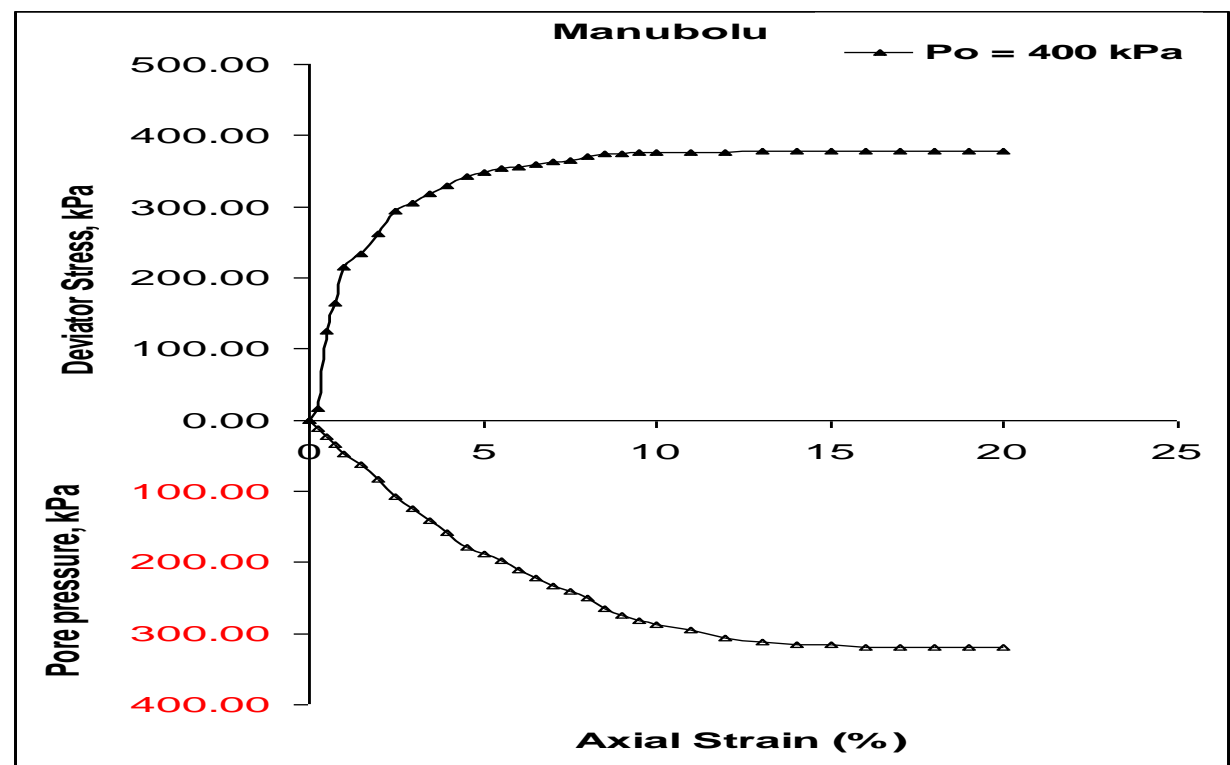

Fig. 24.Stress-Strain-Pore water pressure response of compacted soil under confining pressure $400 \mathrm{kPa}$ - For Manubolu soil

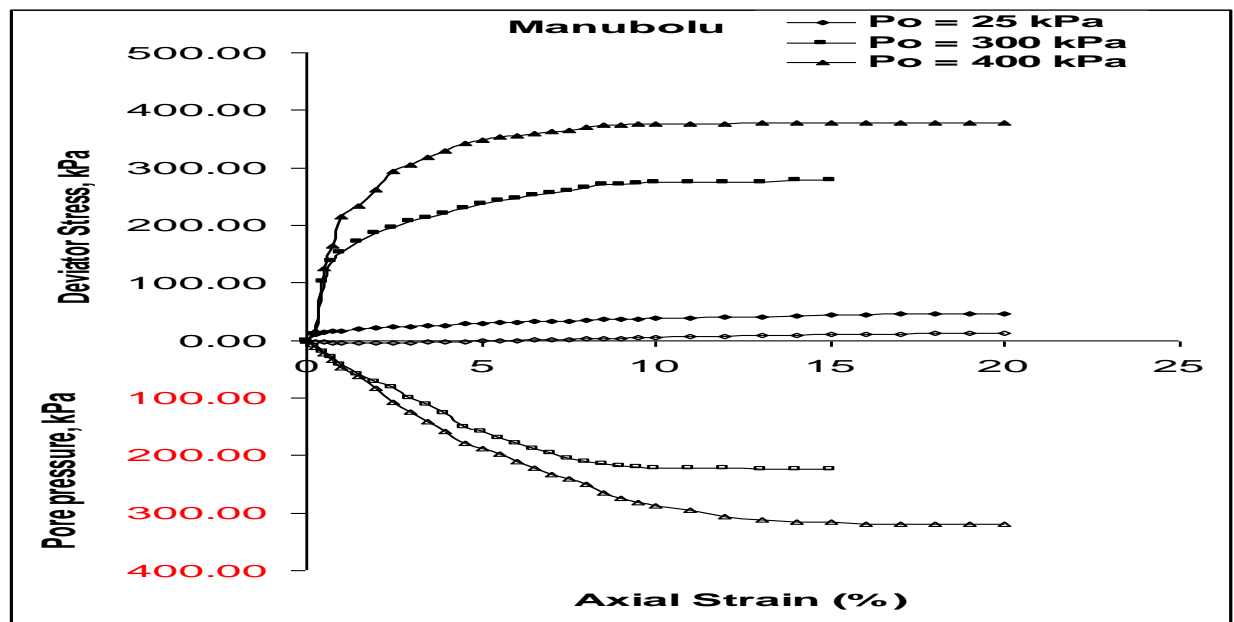

Fig. 25. Stress-Strain-Pore water pressure response of compacted soil - For Manubolu soil 


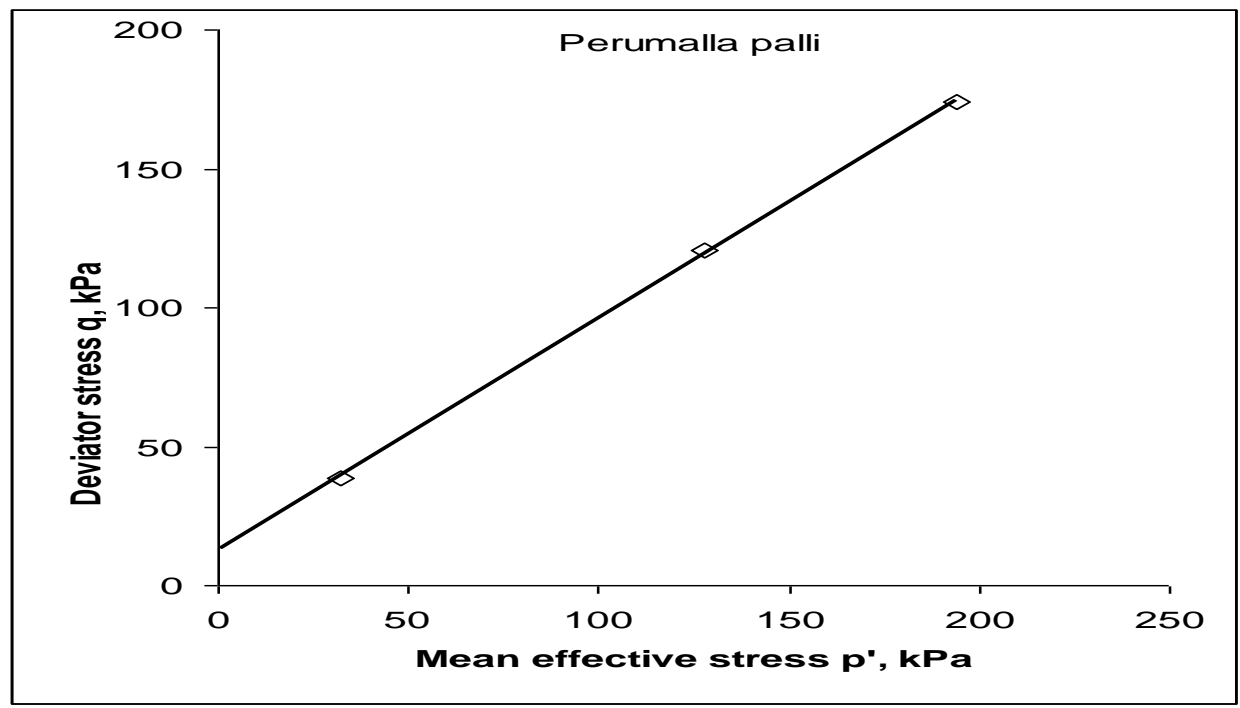

Fig. 26. Deviator stress plotted against mean effective stress at critical state

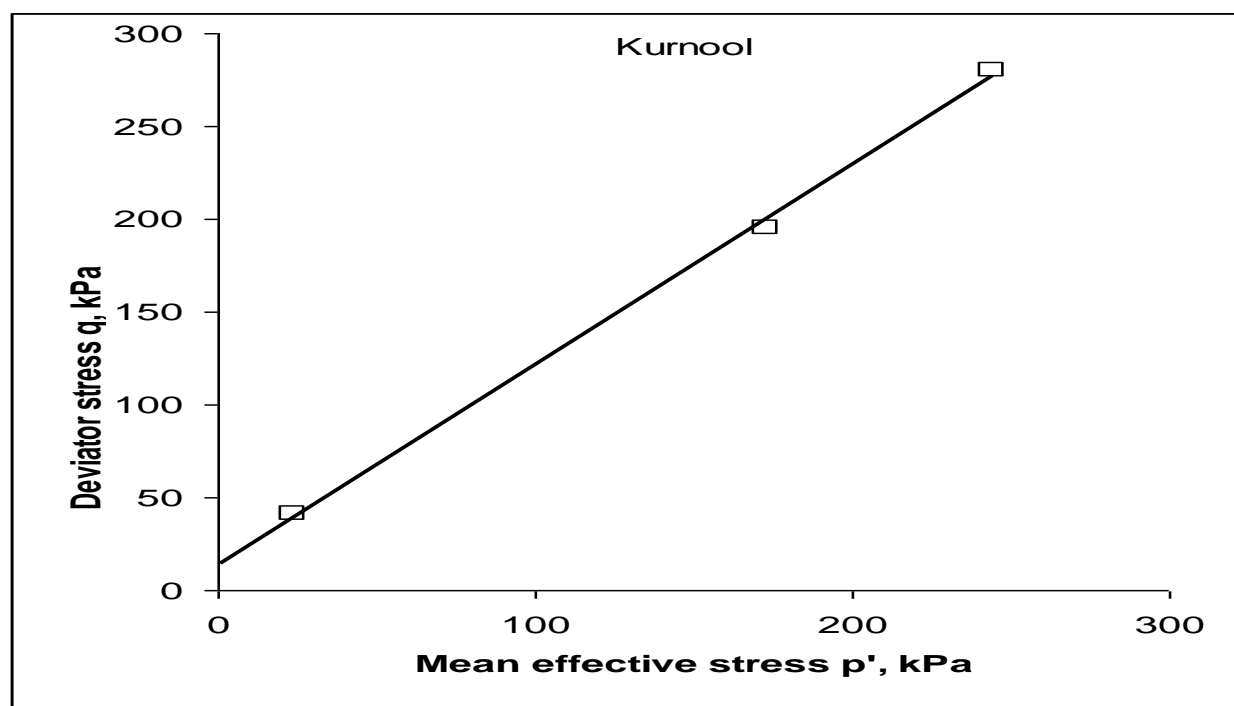

Fig. 27. Deviator stress plotted against mean effective stress at critical state

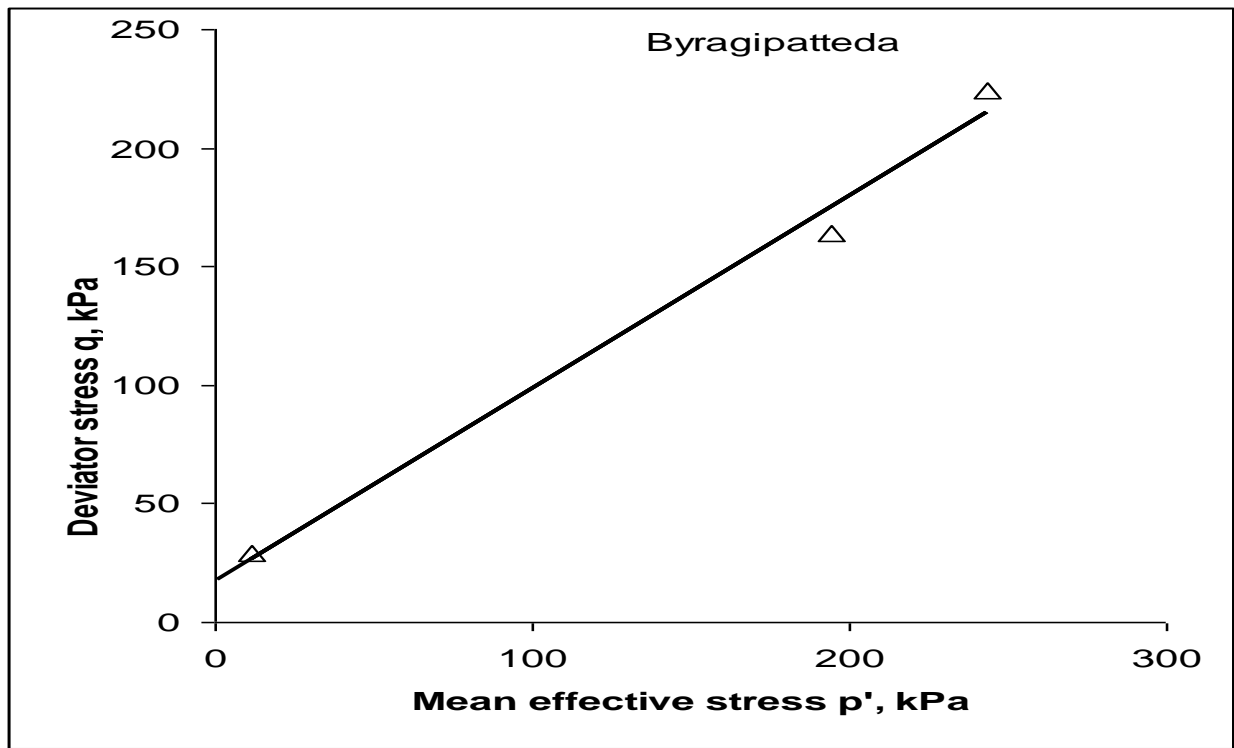

Fig. 28. Deviator stress plotted against mean effective stress at critical state 


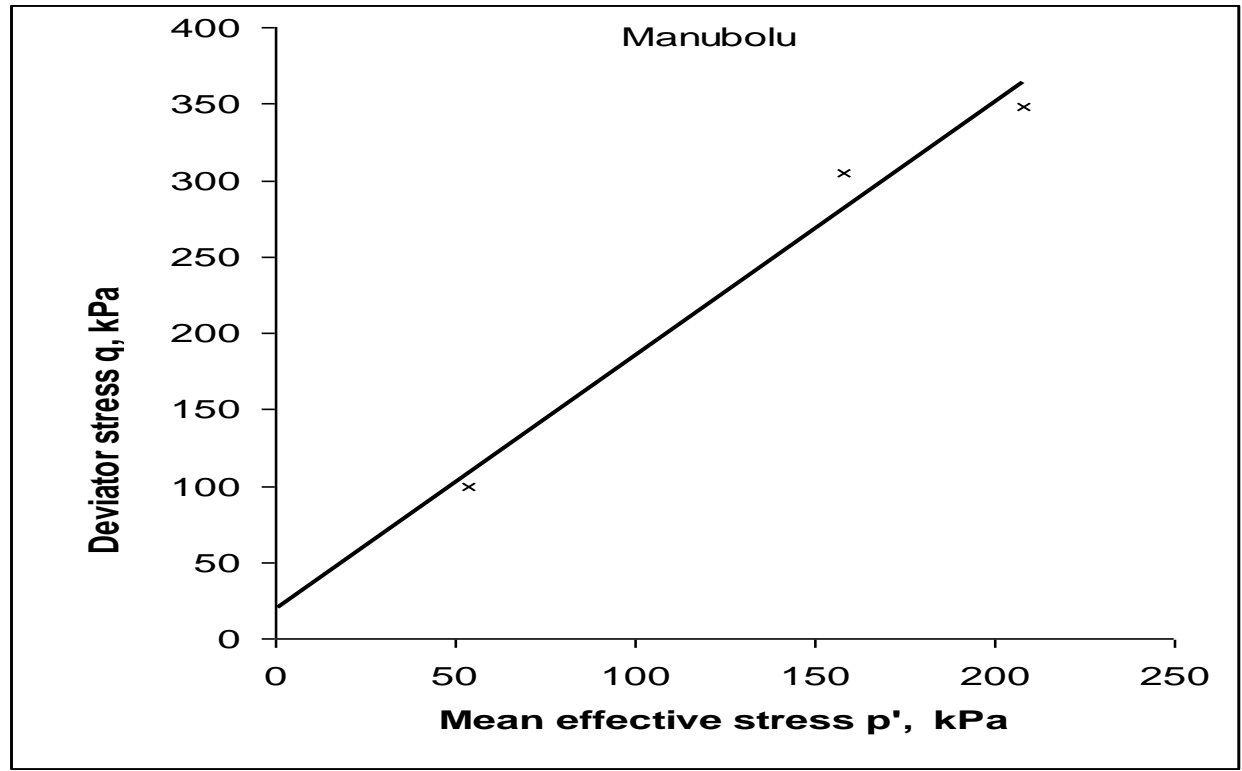

Fig. 29. Deviator stress plotted against mean effective stress at critical state

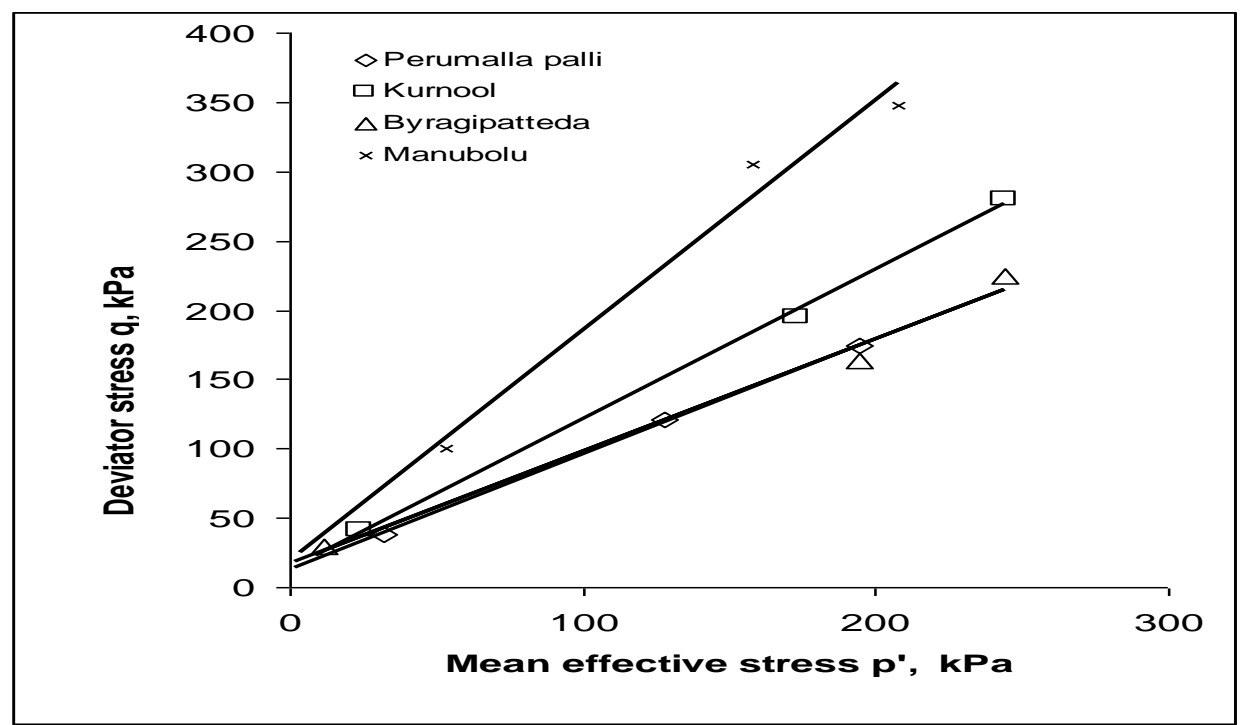

Fig. 30.Deviator stress plotted against mean effective stress at critical states

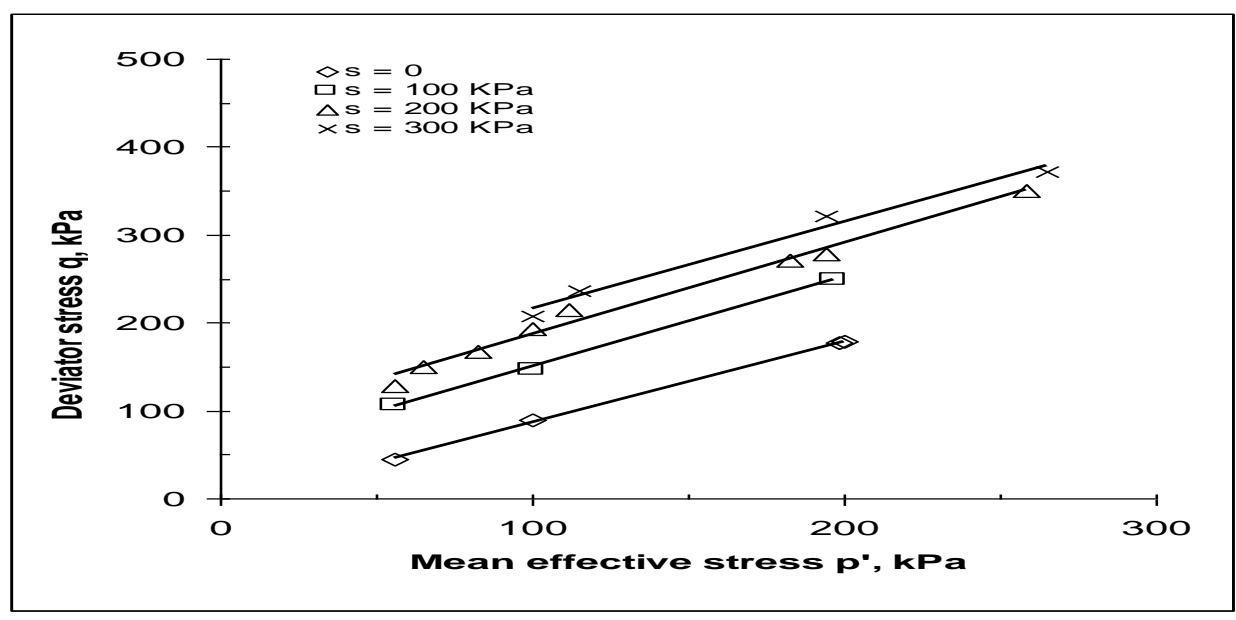

Fig. 31.Deviator stress plotted against mean effective stress at critical states (data from Wheeler \& Siva Kumar (1995)) 


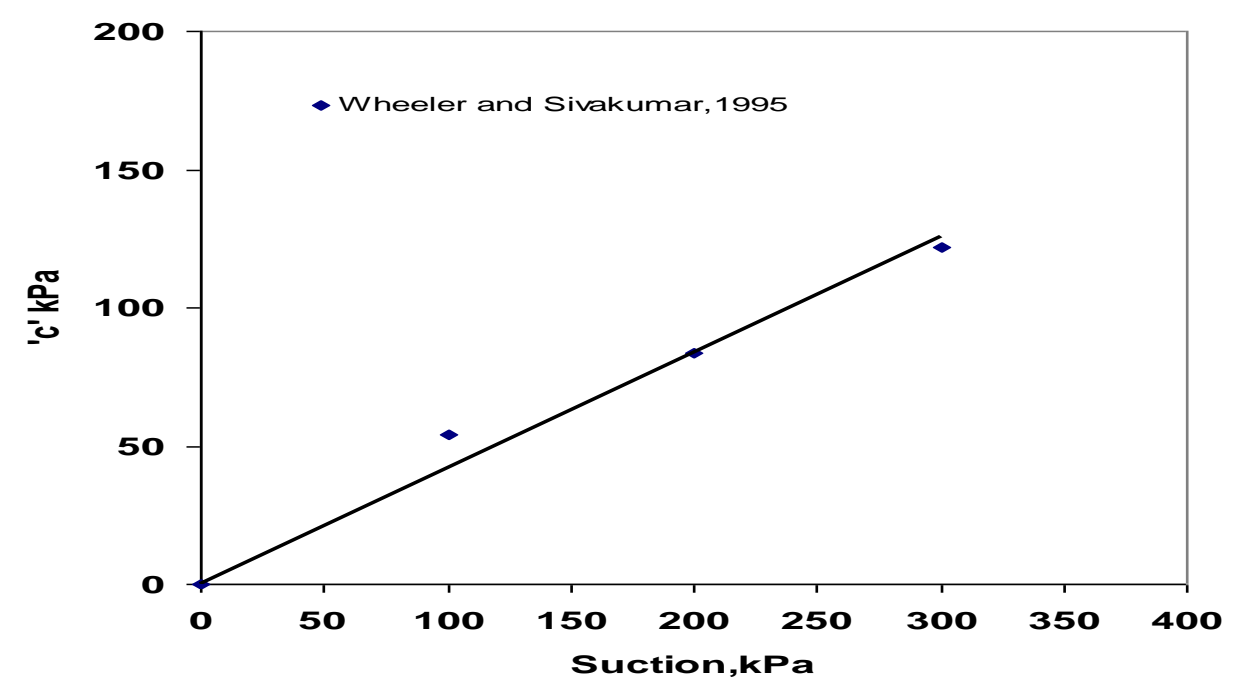

Fig. 32.Suction vs. the value of 'c' (data from Wheeler \& Siva Kumar(1995))

\section{Conclusion}

Based on experimental results on soil samples considered in the present investigation the following concluding remarks may be made.

1. The compression paths for unsaturated soils at initially loose state are likely to converge with the normal compression line for saturated soils as a consequence of increase in saturation observed with increase in stress.

2. The compression index of unsaturated soils can be obtained from the relationship obtained with $e \sqrt{s_{r}}$ and equilibrium pressure for those soils which represent initially loose state.

3. The compaction curves for the soils are noticed to be placed according as their respective plastic limit and modified plastic limit values. These experimental findings indicate that the compaction characteristics relate to plastic limit and modified plastic limit.

4. The soils tested tend to collapse under inundation as the resistance to compression reduces with increase of pore water and hence increase in effective stress.

5. The experimental investigation reveals that the soils compressed from initially loose and unsaturated state lie on the right hand side of the normal compression line of same soil compressed under saturation.

6. The soil samples compressed from compacted state corresponding to optimum moisture content lie on left hand side of the normal compression line.

7. The compression paths of the compacted specimens are akin to that of over consolidated state. These compression paths yield at very high stress levels.

8. The stress strain response for the compacted soils is dependent on confining pressure though the initial void ratios are nearly same. Greater the confining pressure greater is the peak stress.

9. This intercept ' $c$ ' is observed to be a characteristic feature of compacted soils on deviatoric stress vs. mean effective stress plot.

\section{References}

[1] Reeve, M.J. and Carter, A.D. Soil analysis physical methods. Edited by Keilth, A.S and Chris, E.M. (Books in soils, plants and environment 1991).

[2] Cruz, P.T., etal. Peculiarities of tropical lateritic and saprolitic soils used as construction materials, selection, control andacceptance criteria - Dams. Progress Rep. of Com. on tropical and saprolitic soils, Brazilian society of soil mechanics, 1985, $275-327$.

[3] White, N.F., Duke, H.R., Sunada, D.K., and Corey, A.T. Physics of desaturation in porous materials. J.Irrig. and drain.Div.,ASCE, 96(2), 1970, 165-191.

[4] Vanaplli, S.K., Fredlund, D.G., Pufahl, D.E., and Clifton, A.W. Model for the prediction of shear strength with respect to soil suction. Can. Geotech.J., 33,1996, 379-392.

[5] S J Wheeler, V Sivakumar (1995). An elosto-plastic critical state frame work for unsaturated soils, Geotechnique 45, No. 1. 1995, 3553 